\title{
The phytoplankton of Guanabara Bay, Brazil. I. Historical account of its biodiversity
}

\author{
Maria Célia Villac ${ }^{1,2}$ \& Denise Rivera Tenenbaum ${ }^{1}$ \\ ${ }^{I}$ Departamento de Biologia Marinha, Instituto de Biologia, Universidade Federal do Rio de Janeiro - UFRJ, \\ Cidade Universitária, CCS-A, CEP 21941-617, Rio de Janeiro, RJ, Brazil \\ ${ }^{2}$ Corresponding author: Maria Célia Villac,e-mail: celiavillac@gmail.com
}

VILLAC, M.C. \& TENENBAUM, D.R. The phytoplankton of Guanabara Bay, Brazil. I. Historical account of its biodiversity. Biota Neotrop. 10(2): http://www.biotaneotropica.org.br/v10n2/en/abstract?inventory+ bn02410022010.

Abstract: This is a historical account of the biodiversity of phytoplankton in Guanabara Bay, Brazil. It is based on 57 publications that refer to sampling carried out between 1913 and 2004. The publications included are those with direct microscopic identification. Although $80 \%$ of the studies focus on ecological issues that tend to mention only the most abundant species, 24 publications provide comprehensive check-lists at the species level, especially of taxa $\geq 20 \mu \mathrm{m}$. The inventory of species includes, to date, 308 taxa among 199 diatoms, 90 dinoflagellates, 9 cyanobacteria, 5 euglenophyceans, 1 chlorophycean, 1 prasinophycean, 1 silicoflagellate, and 2 ebriids. The most conspicuous species were the dinoflagellate Scrippsiella trochoidea and diatoms from the Skeletonema costatum complex. The first was the theme of the very first publication in the area (Faria 1914) that reported on its bloom associated with the mass mortality of fish due to oxygen depletion; it is still often found in high abundances $\left(10^{6}\right.$ cell. $\left.\mathrm{L}^{-1}\right)$ in more protected areas. The second was long considered in the literature as a cosmopolitan and opportunistic species, until the recent discovery of cryptic species within the genus; taxonomic re-evaluation of local populations is, therefore, needed. Besides these two species, only other 25 species stood out in terms of frequency of occurrence and widespread distribution in the Bay, some known to be implicated in harmful blooms elsewhere. The biodiversity of dinoflagellates, especially within the Gymnodiniales, and that of other unidentified flagellates (Haptophyceae, Cryptophyceae, Prasinophyceae, Raphidophyceae) is largely underestimated because of the use of fixatives that distort/destroy diagnostic characters. From the initial inventory of 124 taxa published in 1917 and the subsequent additions in species numbers, one can have a false perception that the phytoplankton biodiversity has increased throughout the years, despite the overall increase in eutrophication observed in Guanabara Bay. The reason for this may be twofold: 1) it is an artifact caused by our progressively improving technical capability to detect and identify species and 2) the possible effects of eutrophication could be better perceived when the community structure is evaluated, that is, when space-time variations in the abundances of the populations (rather than just number of species) are also taken into account.

Keywords: marine microalgae, diatoms, dinoflagellates, cyanobacteria, algal blooms.

VILLAC, M.C. \& TENENBAUM, D.R. O fitoplâncton da Baía de Guanabara, Brasil. I. Histórico da biodiversidade local. Biota Neotrop. 10(2): http://www.biotaneotropica.org.br/v10n2/pt/abstract?inventory+ bn02410022010.

Resumo: Este é o histórico dos estudos sobre a biodiversidade do fitoplâncton da Baía da Guanabara, Brasil, com base em 57 publicações relativas a amostras coletadas no período entre 1913 e 2004. Estão aqui incluídas apenas as investigações que identificaram espécies por microscopia. Apesar de $80 \%$ dos estudos serem de cunho ecológico, os quais tendem a citar apenas as espécies mais abundantes, 24 publicações incluem listas completas dos táxons identificados em nível específico, especialmente daqueles $\geq 20 \mu \mathrm{m}$. Atualmente, o inventário de espécies inclui 308 táxons dentre 199 diatomáceas, 90 dinoflagelados, 9 cianobactérias, 5 euglenofíceas, 1 clorofícea, 1 prasinofícea, 1 silicoflagelado e 2 ebriideos. As duas espécies que mais se destacaram foram o dinoflagelado Scrippsiella trochoidea e diatomáceas do complexo Skeletonema costatum. A primeira foi o tema de publicação pioneira sobre o fitoplâncton da Baía (Faria 1914), que relatou sua floração associada à mortandade de peixes, e continua sendo detectada em altas concentrações $\left(10^{6}\right.$ cell. $\left.\mathrm{L}^{-1}\right)$ em áreas mais protegidas. A segunda foi considerada por muitos anos na literatura como uma espécie cosmopolita e oportunista, até a descoberta recente de espécies crípticas dentro do gênero, indicando que as populações da Baía da Guanabara requerem revisão taxonômica. Além destas duas espécies, apenas 25 apresentaram alta frequiência de ocorrência e ampla distribuição, algumas relatadas como causadoras de florações nocivas em outros locais. A biodiversidade de dinoflagelados, especialmente dentre os Gymnodiniales, assim como a de outros grupos de flagelados ainda não identificados (Haptophyceae, Cryptophyceae, Prasinophyceae, Raphidophyceae), está subestimada devido ao uso de fixadores que destorcem ou destroem caracteres diagnósticos. Se considerarmos o inventário de espécies mais antigo, uma lista de 124 táxons publicada em 1917, e o incremento no número de espécies desde então, é possível ter a falsa impressão de que a biodiversidade do fitoplâncton da Baía de Guanabara aumentou apesar da crescente eutrofização local. Há dois motivos possíveis: 1) trata-se apenas do reflexo do aprimoramento da capacidade técnica de detectar e identificar as espécies e 2) os efeitos potenciais da eutrofização podem ser melhor percebidos através da análise da estrutura da comunidade, ou seja, quando as tendências espaciais e temporais na abundância das populações (e não apenas no número de espécies) são levadas em consideração.

Palavras-chave: microalgas marinhas, diatomáceas, dinoflagelados, cianobactérias, florações algais. 


\section{Introduction}

The remarkable diversity of phytoplankton has been a matter of standing discussion for many years, a debate also known as the "paradox of the plankton" (Hutchinson 1961). This topic has an ecological component and an evolutionary component. The former one deals with the puzzling co-existence of dozens of species in the same parcel of water, all of them potential competitors for the same resources (nutrients) that are often at limiting concentrations. Three lines of thought have provided possible mechanisms to unravel this paradox and it is likely that these forces may act in conjunction with one another. First, the competition for resources takes place in an unstable environment, that is, the frequency and intensity of disturbances (in the water column and intrinsic to the competition itself) are intermediate to the time necessary for species succession to achieve any type of equilibrium that could favor the dominance of a few species and exclusion of others (Reynolds et al. 1993, Hulsman \& Weissings 1999, Scheffer et al. 2003). Second, species have different strategies in terms of size, shape and cell content to cope with the need for keeping afloat, sink, rise, and/or rotate and, therefore, may take advantage of different (perhaps overlapping) niches within the photic layer (Smayda 1970). An third, differential advantage due to defense against grazing, such as that afforded by larger specimens, chain forming ones, those with tougher cell walls, and the production of bioactive compounds (Smetacek 2001). If one considers that these forces have been in place for millions of years, this leads us to the evolutionary component of this debate.

A common feature to most (but not all) phytoplankton species is the presence of the photosynthetic organelle, the plastid. However, it is not yet totally resolved which of the photosynthetic forms are united on a single branch of the tree of life through vertical endosymbiosis and which have plastids that have spread by multiple independent events (Bhattacharya et al. 2003). When dealing with the early evolution of eukaryotic diversity, as stated by Baldauf (2003), "to (nearly) every rule there is an exception". The end result is that the present-day phytoplankton community at a given space and time can be comprised of species that span at least 3 orders of magnitude in size (from 2 to $200 \mu \mathrm{m}$ ) and includes representatives of various taxonomic lineages, in consonance with classification systems available to date. Phytoplankton species fit into three out of the five "kingdoms" established in the more traditional classification of Whittaker (1969): Monera, Protista, and Plantae. In the more recently established classification of Adl et al. (2005), phytoplankton species fit into four of the six "super-groups": Rhizaria, Archaeplastida, Chromalveolata, and Excavata.

The most successful phytoplankton groups in the modern ocean, that is, those that became the dominant assemblages since the Mesozoic, are diatoms, dinoflagellates and haptophytes (Simon et al. 2009). The most recent unabridged account of the phytoplankton diversity of the world's oceans is still that of Sournia et al. (1991). This review includes 17 classes, $498 \pm 15$ genera, and 3,910 \pm 465 species; diatoms account for 1,365-1,783 species, dinoflagellates for 1,424-1,772, and coccolithophorids (within haptophytes) for 239-298. According to the authors, the higher estimate included little known or doubtful species, whereas the lower estimate is a better approximation of the taxa whose taxonomy seemed more reliable at the time. Since then, our perception of biodiversity has changed dramatically, mostly due to the intense use of electron microscopy and of molecular techniques. Nevertheless, a recent and more accurate inventory of the phytoplankton diversity of the world's oceans is not available, except for one group: there are 1,555 species within 117 genera of extant free-living marine dinoflagellates, with 135 new species described between 1993 and 2003 (Gómez 2005). An appraisal of the biodiversity of the algae as a whole indicated that the total number of undescribed species may exceed present-day estimates by a factor of four to eight, depending on the group (Norton et al. 1996).

Some taxonomic novelties are merely in re-arranging taxa around so that certain ranks are resurrected or new ones are created to accommodate previously described species. Selected examples of such cases are those species of the diatom Rhizosolenia Brightwell that were transferred to genera described long ago as Guinardia H. Peragallo and Dactyliosolen Castracane or to newer ones as Proboscia Sundström and Pseudosolenia Sundström (Hasle \& Syvertsen 1997); the splitting of the naked dinoflagellates within Gymnodinium Stein into three additional genera, Akashiwo G. Hansen \& Moestrup, Karenia G. Hansen \& Moestrup, and Karlodinium J. Larsen (Daugbjerg et al. 2000); and the marine forms of Ceratium F. Schrank that should now be considered as Neoceratium F. Gómez, D. Moreira \& P. López-García (Gómez et al. 2009). In other cases, however, there is a true increase in the actual number of species to consider (or varieties, or genotypes). Cryptic diversity has been found to be widespread in coccolithophorids (Geisen et al. 2004), in diatoms such as Skeletonema Greville (Sarno et al. 2007) and Pseudo-nitzschia H. Peragallo (Villac et al. 2010), and in dinoflagellates such as Scrippsiella Balech ex A.R. Loeblich III (Montresor et al. 2003), Amphidinium Claperède \& Lachmann (Murray et al. 2004), and Alexandrium Halim (Lilly et al. 2007). These are but a few examples found among the larger-sized species $(>5-10 \mu \mathrm{m})$. Even more striking is that we are just beginning to grasp a better appreciation of the diversity hidden in the smaller fraction (picoplankton, cells $\leq 2 \mu \mathrm{m}$ ) of phytoplankton communities (e.g., Not et al. 2006, Vlprey et al. 2008).

The marine phytoplankton check-list for Brazilian waters includes at least 1,364 species of which 783 are diatoms, 364 dinoflagellates, and 96 coccolithophorids (Tenenbaum 2002, based on Banco de Dados Tropicais - BDT). The higher proportion of diatoms is probably a consequence of a stronger background of local diatomists, although more recent advances have been made in other groups, e.g., dinoflagellates (Tenenbaum 2006) and other nanoflagellates (Bergesch et al. 2008). Local and regional inventories are most often found in academic theses/dissertations and technical reports and few of those studies have been published in scientific journals of wider circulation (e.g., Tenenbaum et al. 2004a, b, Procopiak et al. 2006, Villac et al. 2008). This scenario reflects the trend, in Brazil and worldwide, to privilege funding for and dissemination of process-oriented research rather than fostering and broadcasting taxonomic investigations, despite the international cry for biodiversity studies that has been taking place for at least the past 20 years (Wilson 1988, Feldmann $\&$ Manning 1992). Scientific journals do not have page-budgets to print long species lists, a limitation that has been overcome with the advent of electronic journals. Species lists provide the baseline for knowing and preserving the tree of life by guiding further research and supporting the assessment of conservation priorities.

The publication of a species list for the phytoplankton of Guanabara Bay, Brazil, is long due. This is a tropical, estuarine system that has undergone man-mediated stresses since the establishment of earlier settlements around its margins in the 1600's, a time when whales came to reproduce in the pristine waters of the bay (Sarthou 1964). The earliest impacts to this system were whaling (with complete decimation by the early 1800's), drainage of some mangrove areas, coastal landfills to allow for urban expansion, and overall city run-off mostly of organic matter (Coelho 2007). At present, the urban area at the drainage basin surrounding the bay has reached 11 million inhabitants (from ca. 800 thousand in 1900) and it is the second largest industrial pole of the country (Brasil 2008). Without the appropriate infrastructure to face the challenges 
of this accelerated economic growth, Guanabara Bay has become the final destination for the dilution of domestic and industrial wastes. Better water quality is found in areas away from the margins and from the inner-reaches of the bay that are closer to pollution sources (Mayr et al. 1989). Such gradient is due to a gravitational and transverse residual tidal circulation that promotes the renewal of $50 \%$ of the bay water with cleaner coastal water in about 11 days (Kjerfve et al. 1997). Despite years of mistreatment, this system is still not only beautiful (the so-called postcard of Rio de Janeiro), but it also hosts a striking biodiversity that deserves the attention of the scientific community, policy makers and the public in general. Here we present a phytoplankton species list that represents a composite of various sampling sites from distinct areas of the bay (Figure 1), accompanied by the historical account of the evolution of methods and approaches used since the pioneer studies.

\section{The Data Set (Figure 2, Appendix 1)}

There is about one century of information produced on the composition and abundance of phytoplankton populations from Guanabara Bay. To the present date, phytoplankton data is available in 57 publications that refer to sampling carried out between 1913 and 2004 whose respective publishing dates are 1914 and 2007. The publications included here are those that present direct microscopic identification at different taxonomic levels (from class to species) mostly of larger size taxa (cells $\geq 20 \mu \mathrm{m}$ ). Studies that estimated solely phytoplankton biomass by pigment analysis and/or assessed primary productivity are not included in this account.

Most of the information (78\%) is available as abstracts in conference proceedings and in scientific journals. Although fewer in number, technical reports and academic monographs from bachelors degrees, masters and doctorates are very important because they include a wealth of detailed information as well as valuable species lists. The reader will find some redundancy in the information contained in Appendix 1 that describes various features of the 57 papers covered here. This is due to the fact that the data of some particular surveys have been partially published as an abstract, followed by the publication of the corresponding academic monograph that later became, in part or in full, a journal article.

The complete species list is found in Appendix 2. As expected, it was necessary to update the nomenclature used in species names. It was beyond the scope and possibility of the present work, however, to question or validate the identifications given in studies other than those published by the authors themselves.

\section{The Historical Account (Figure 3, Appendix 1)}

The first five studies about the phytoplankton of Guanabara Bay were published by investigators associated with the research institute "Manguinhos", presently known as "Fundação Instituto Oswaldo Cruz (FIOCRUZ)". The first study pointed out the effects of an algal bloom that occurred in 1913 (Faria 1914). The phenomenon was caused by the dinoflagellate Scrippsiella trochoidea (Stein) Loeblich III (then identified as Glenodinium trochoideum) and caused mass mortality of fish due to oxygen depletion. This is the very first record of a harmful algal bloom on the Brazilian coast. At about the same time, the survey of Faria \& Cunha (1917) stands out as a pioneer and very comprehensive species inventory that serves as a baseline documentation of a time when Guanabara Bay still had pristine waters. Two decades passed by without a single citation, until the

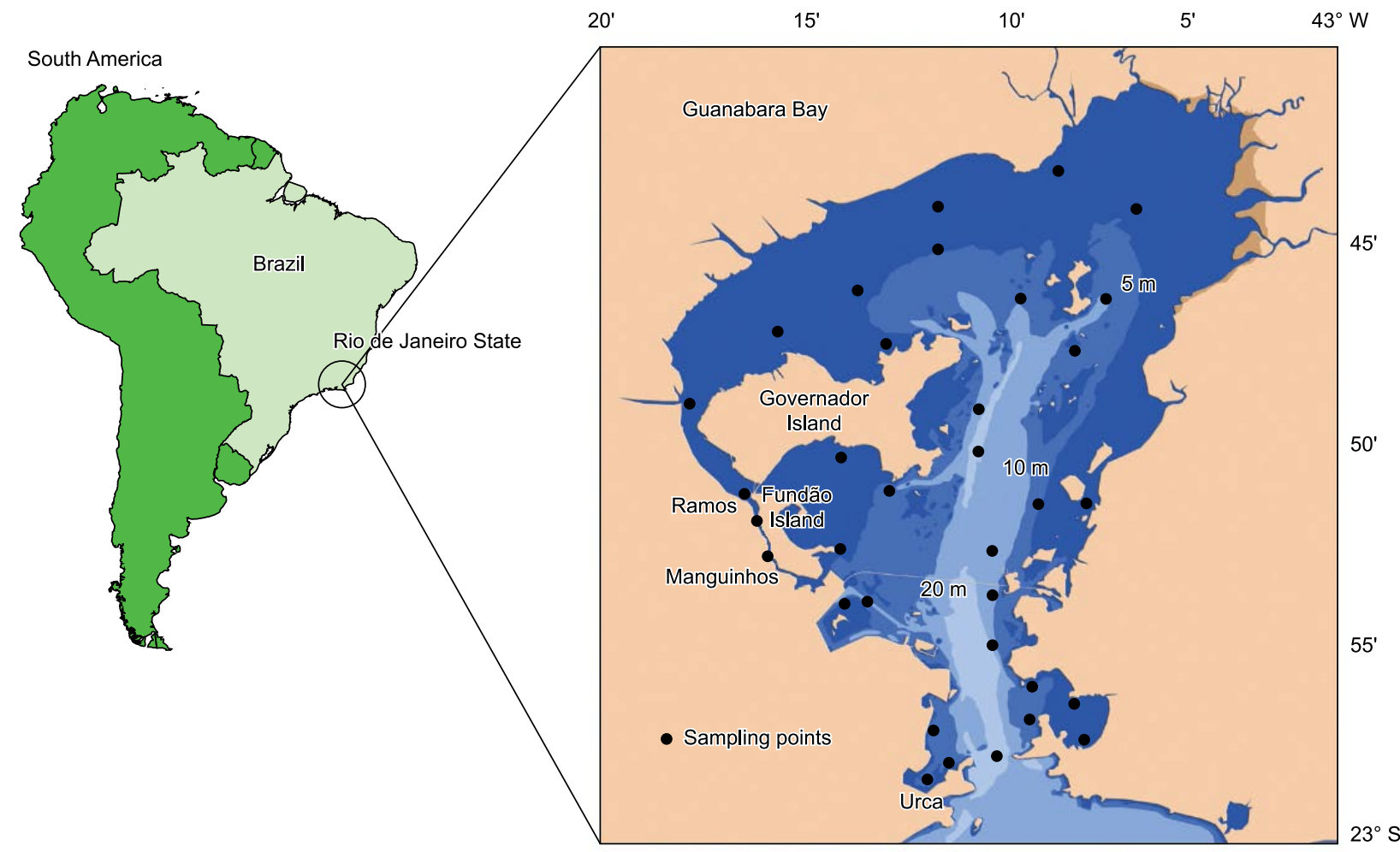

Figure 1. Guanabara Bay. Between 1913 and 2004, 34 sites located in distinct areas within the bay were visited for phytoplankton sampling. 


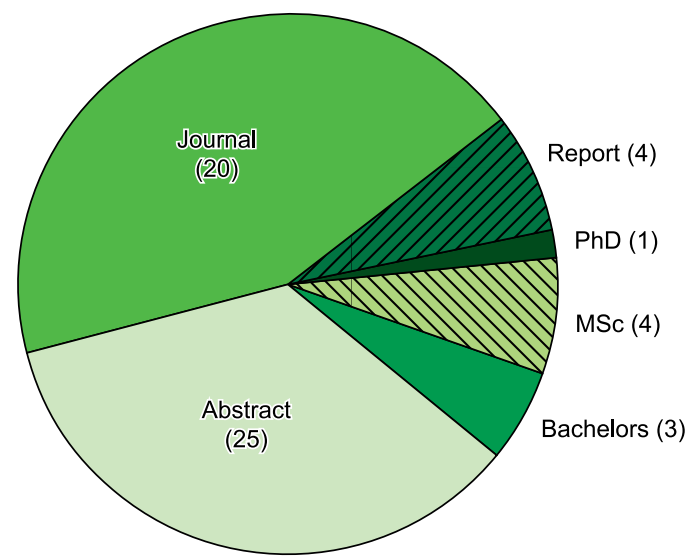

Figure 2. Types of publications in which phytoplankton information is available.

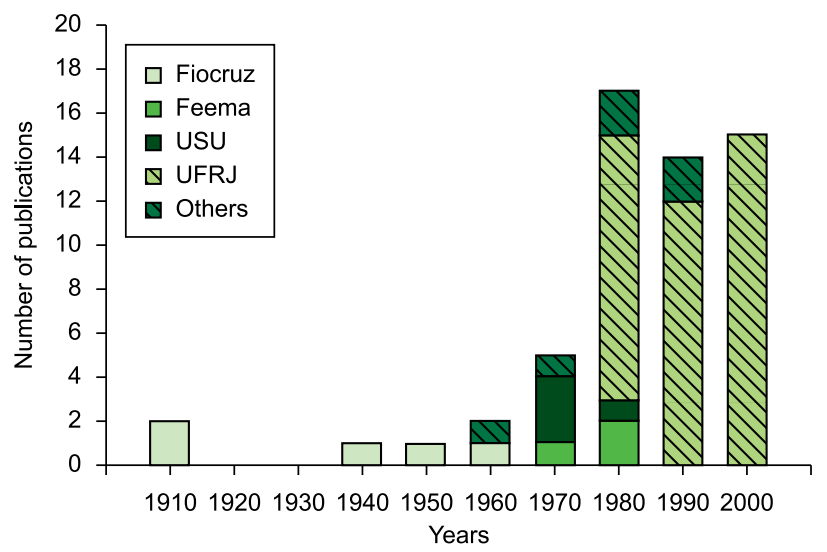

Figure 3. Historical record of phytoplankton studies, pointing out the various research institutions involved. Dates (in years) indicate either the sampling period or, in case of secondary data used in review studies, the year of publication. Legend: FIOCRUZ - Fundação Instituto Oswaldo Cruz; FEEMA - Fundação Estadual de Engenharia do Meio Ambiente do Rio de Janeiro; USU - Universidade Santa Úrsula; UFRJ - Universidade Federal do Rio de Janeiro.

publication of a few surveys in the 1940-1960's that already signaled concern about the occurrence of some species considered as indicators of organic pollution (Oliveira 1947, Krau 1958, Oliveira 1962). These later studies were carried out in the Manguinhos area (Figure 1) that, at present, is under a landfill that borders a region along the western margin where water quality is very poor (Mayr et al. 1989).

During the 1970-1980's, the State Environmental Agency (Fundação Estadual de Engenharia do Meio Ambiente do Rio de Janeiro - FEEMA, presently known as INEA, Instituto Estadual do Ambiente) established a monitoring program of the water quality of the bay that included phytoplankton sampling, most often on a monthly basis (Garrido et al. 1978, Soares et al. 1981, Souza et al. 1983). During the same period, the Universidade Santa Úrsula (USU) also carried out some intensive 3 to 6-month time-series making use of some of the sites from the FEEMA sampling grid (Sevrin-Reyssac et al. 1979, Schutze et al. 1989, Vallim \& Machado 1990).

In 1984, the Biology Institute of the Universidade Federal do Rio de Janeiro (UFRJ) started a still on-going program called "The

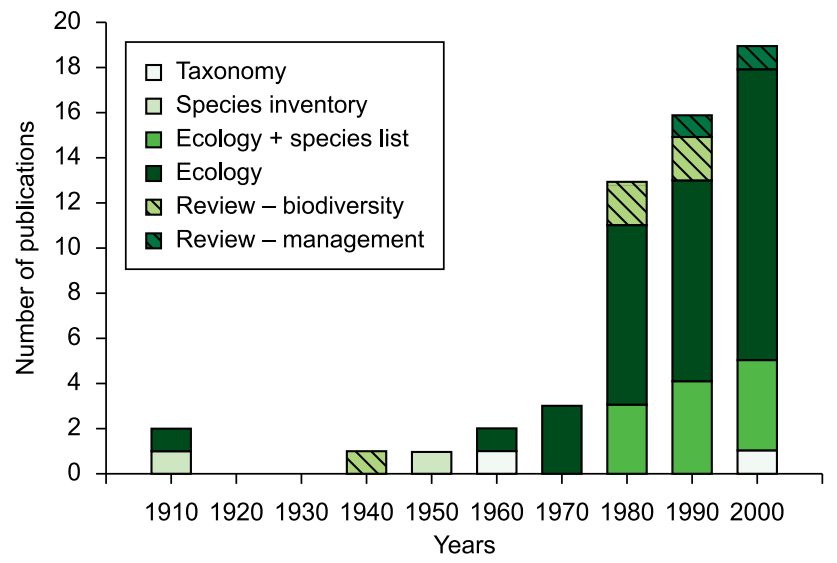

Figure 4. Chronological classification of phytoplankton studies according to focus.

Plankton of Guanabara Bay". During the past 20+ years, and under a range of sub-programs sponsored by a variety of research funds, the composition and abundance of the phytoplankton populations have been examined at various, overlapping space-time scales (from tidal/diel variations to inter-annual cycles, from weekly to monthly sampling and vertical stratification in places of deeper water columns). About $67 \%$ of the publications available at present have derived from this research program (e.g., Villac et al. 1987, 1990, Vallim 1995, Barbosa 1997, Valentin et al. 1999b, Tenenbaum et al. 2001, Santos 2002, Villac et al. 2004, Lima 2007).

\section{The Focus (Figure 4, Appendix 1)}

Out of the 57 publications considered in this assessment, only two discuss taxonomic issues in particular (Balech \& Soares 1966, Villac et al. 2001) and in another two the central point is the species inventory (Faria \& Cunha 1917, Krau 1958). About $80 \%$ of the studies published to date focus on ecological aspects, that is, these are studies that aim to understand space-time distributions of phytoplankton populations and their relationship with possible controlling factors such as temperature, salinity, nutrients and density gradients. The majority of such studies tend to mention only the most abundant species and only 9 of them include a complete list of the species found (Braga 1980, Soares et al. 1981, Silva et al.1988, Villac 1990, Vallim 1995, Barbosa 1997, Santos 1999, 2002, Lima 2007).

Two review publications came out in 1947 and 1980, with similar objectives: to trace the biogeography of phytoplankton populations (Oliveira 1947, Sevrin-Reyssac 1980). As data about plankton and water quality in general accumulated throughout the years, a number of robust review studies became possible (Valentin et al. 1997, 1999b), some of them with a clear management rationale in which the phytoplankton community structure and/or some species in particular could be used as bio-indicators of water quality (Mayr et al. 1989, Villac et al. 1991, SECT 2000).

\section{The Methodological Approach (Figure 5, Appendix 1)}

As mentioned before, those studies that focused on taxonomy and on species inventories (Figure 4) represent only $8 \%$ of the data available; these are here classified as having a qualitative approach (Figure 5). There are also very few studies considered as solely quantitative $(8 \%)$, of which it is interesting to note the pioneer investigation done by Barth (1972) that evaluated the nanoplankton fraction (cells $<20 \mu \mathrm{m}$ ) and used a Coulter counter. 


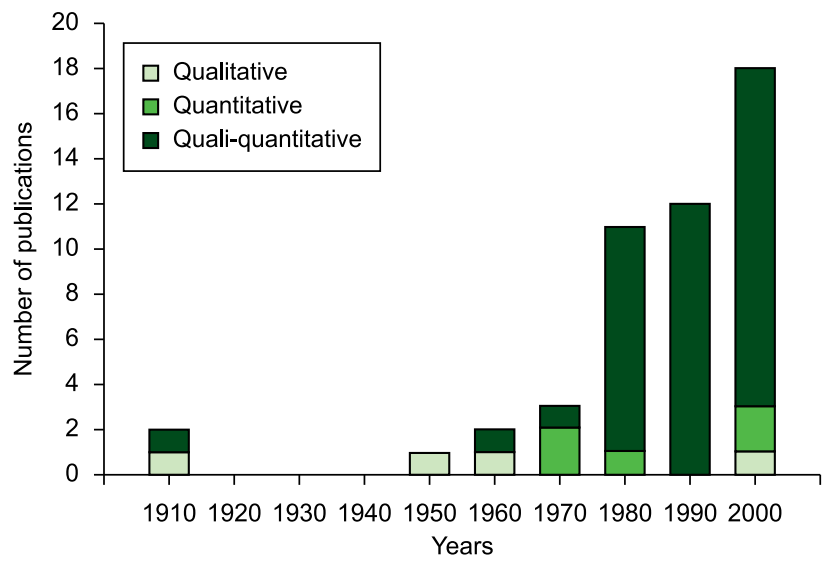

Figure 5. Chronological classification of phytoplankton studies according to methodological approach.

The approach most frequently used, especially during the past 3 decades, was here considered as quali-quantitative (Figure 5), that is, species identification combined with cell numbers in studies that focused on ecological issues (Figure 4). It is noteworthy that only the surveys of Faria (1914) and Oliveira (1962) employed counting techniques that relied on cell concentration by centrifugation, whereas the other studies used the Utermöhl's settling technique. A sampling bottle was used in all quali-quantitative studies, because this sampling device allows for the results to be expressed in number of cells per unit of volume. Phytoplankton nets were employed only in the qualitative surveys carried out in the early 1900's, during the FEEMA's monitoring program and by the UFRJ research group from 1997 onward. Samples taken by net hauls do not allow for the precise estimate of cell numbers (refer to Sournia 1978), but it concentrates a high number of cells and is thus ideal for the use of additional techniques necessary for a refined taxonomy. The resurgence of the use of net hauls in the late 1990's reflects the increasing global concern with the loss of biodiversity in impacted environments, therefore the need to better understand the species composition in Guanabara Bay and elsewhere.

Various techniques and methods were applied more recently, bringing up new insights into our understanding of phytoplankton biodiversity/ecology in the area, as follows: epifluorescence microscopy to discriminate autotrophs from heterotrophs (e.g., Santos et al. 1999a, Tenenbaum et al. 2001, Santos 2002, Lima 2007); electron microscopy to visualize ultra-structures that are key taxonomic characters (e.g., Villac \& Tenenbaum 2001, Matos et al. 2002, Villac et al. 2004); and the assessment of cell bio-volume to express biomass in terms of carbon content (Tenenbaum et al. 2001, Santos 2002, Santos et al. 2006).

In terms of sampling and analysis, phytoplankton surveys share several features with other studies such as pigment composition, primary production and the occurrence of ciliates. This is valuable information and, if any of this type of data was carried out in conjunction with a given phytoplankton investigation, it is discriminated as such in Appendix 1.

\section{The Biodiversity: General Aspects (Figure 6, Appendix 2)}

The inventory of the phytoplankton species found in Guanabara Bay includes, to date, 308 taxa among 199 diatoms, 90 dinoflagellates, 9 cyanobacteria, 5 euglenophyceans, 1 chlorophycean, 1 prasinophycean, 1 silicoflagellate, and 2 ebriids. The larger number of diatoms (62\%) and dinoflagellates (32\%) is notunexpected.Ascitedearlier, the review of Sournia

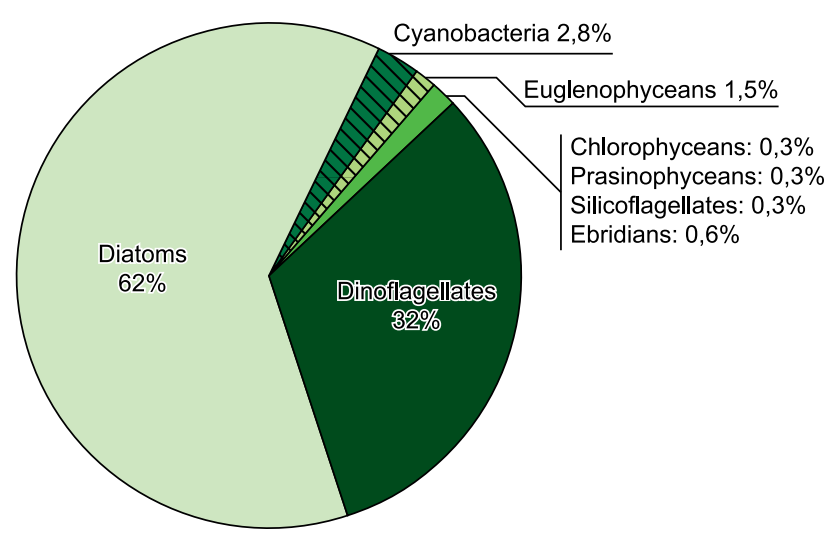

Figure 6. Comparison of the relative number of taxa within various taxonomic groups.

et al. (1991) estimated the number of phytoplankton species of the world's oceans as follows: 1,365-1,783 diatoms, 1,424-1,772 dinoflagellates, 239-298 coccolithophorids, 106-121 chlorophyceans, 95-128 prasinophyceans, 94-124 chrysophyceans, 56-73 cryptophyceans, and 35-36 euglenophyceans, just to mention the most numerous classes. The larger number of diatoms is a trend observed for other regions along the Brazilian coast as found in Sepetiba Bay (Tenenbaum et al. 2004a, b) and along the coast of the States of São Paulo (Villac et al. 2008) and Paraná (Procopiak et al. 2006). Although high diversity of diatoms can be anticipated in coastal areas (refer to various examples in Hasle \& Syvertsen 1997), as mentioned before, diatomists have had a stronger historical influence among Brazilian scientists than researchers of other taxonomic groups.

The biodiversity of dinoflagellates in the bay is furthermore underestimated because of the occurrence of several still unidentified taxa belonging to the Order Gymnodiniales, a group whose fragile cell walls would require the study of live cells, a strategy seldom employed. The use of fixatives, such as formaldehyde, distort the overall shape of the gymnodinioid cells and can damage important taxonomic characters (flagella and/or grooves) essential for a precise identification. This limitation also applies to other delicate, thus far unidentified, flagellates that are often grouped at the Class level (Haptophyceae, Cryptophyceae, Prasinophyceae, Raphidophyceae).

It is noteworthy that about $25 \%$ of the dinoflagellates identified to date are heterotrophic, several of them belonging to the genus Protoperidinium Bergh (Santos 2002). Similarly, the ebriid species Ebria tripartita (Schumann) Lemmermann and Hermesinum adriaticum Zacharias are both obligate heterotrophs that have a very unstable classification track record (Hoppenrath \& Leander 2006); they were maintained in the phytoplankton species list because of historical reasons, that is, in the past they have been classified among silicoflagellates (Drebes 1974) and dinoflagellates (Sournia 1986).

\section{The Biodiversity: New Records and Special Occurrences (Figure 7, Table 1)}

For a more detailed assessment of the history of phytoplankton biodiversity, considering species distribution and frequency of occurrence, we have selected 24 studies that contained check-lists with taxa identified to species level (those marked with an asterisk in Appendix 1). Taken together, this data set corresponds to 34 sampling sites (Figure 1), but some of them were close enough to be combined as a sole record leading to a total of 27 sites. A few studies did not provide any indication of an exact sampling position. Therefore, the 


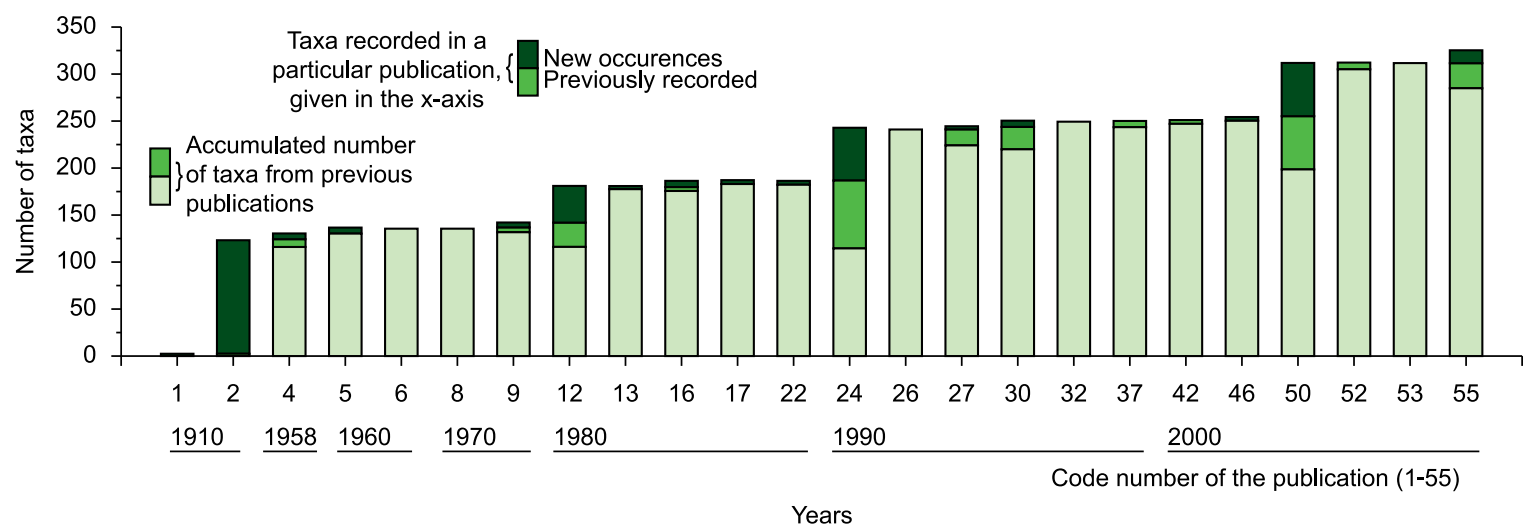

Figure 7. Advances in the understanding of phytoplankton biodiversity throughout the years. Only the 24 publications that have taxa identified to species were included, after eliminating redundancies detected when the same data set was used in more than one citation. See Appendix 1 to associate code number (1-55) with its respective citation. To interpret this graph, take publication 24 as an example: 128 taxa were identified to species, of which 55 are new occurrences (top section in black) and 73 were already previously recorded (mid section in dark green); therefore, these 73 species are part of the cumulative number of species detected in earlier studies (mid section in dark green + bottom in light green).

Table 1. Selected phytoplankton species due to widespread occurrence in the bay (detected in $\geq 25 \%$ of sampling sites, $\mathrm{n}=28$ as explained in the text) and/or because they were found in several studies (cited in $\geq 25 \%$ of the publications, $n=24$ as explained in the text).

\begin{tabular}{|c|c|c|c|}
\hline Taxonomic group & Species & $\%$ Occurrence & $\%$ Citations \\
\hline Bacillariophyceae & Skeletonema costatum & 85 & 42 \\
\hline Bacillariophyceae & Ceratoneis closterium & 80 & 40 \\
\hline Bacillariophyceae & Dactyliosolen fragilissimus & 70 & 25 \\
\hline Bacillariophyceae & Guinardia striata & 67 & 38 \\
\hline Dinophyceae & Prorocentrum micans & 67 & 38 \\
\hline Dinophyceae & Oxyphysis oxytoxoides & 67 & 29 \\
\hline Bacillariophyceae & Nitzschia longissima & 67 & 13 \\
\hline Bacillariophyceae & Leptocylindrus danicus & 63 & 33 \\
\hline Bacillariophyceae & Thalassiosira rotula & 63 & 29 \\
\hline Ebriideae & Ebria tripartita & 63 & 25 \\
\hline Euglenophyceae & Eutreptiella marina & 63 & 21 \\
\hline Bacillariophyceae & Leptocylindrus minimus & 63 & 13 \\
\hline Dinophyceae & Protoperidinium conicum & 63 & 13 \\
\hline Dinophyceae & Protoperidinium steinii & 63 & 13 \\
\hline Bacillariophyceae & Rhizosolenia setigera & 59 & 29 \\
\hline Bacillariophyceae & Thalassionema nitzschioides & 59 & 29 \\
\hline Bacillariophyceae & Cerataulina pelagica & 59 & 21 \\
\hline Dinophyceae & Protoperidinium pellucidum & 59 & 13 \\
\hline Dinophyceae & Protoperidinium pyriforme & 59 & 4 \\
\hline Dinophyceae & Prorocentrum triestinum & 56 & 21 \\
\hline Bacillariophyceae & Hemiaulus sinensis & 52 & 21 \\
\hline Dinophyceae & Prorocentrum balticum & 52 & 8 \\
\hline Bacillariophyceae & Helicotheca tamesis & 52 & 4 \\
\hline Dictyochophyceae & Dictyocha fibula & 33 & 33 \\
\hline Bacillariophyceae & Paralia sulcata & 33 & 25 \\
\hline Dinophyceae & Scrippsiella trochoidea & 22 & 46 \\
\hline Bacillariophyceae & Bacillaria paxillifera & 7 & 25 \\
\hline
\end{tabular}

evaluation of frequency distribution presented in Table 1 was calculated considering $\mathrm{n}=28$ (27 actual sites plus 1 arbitrary site to represent the studies that did not provide coordinates). These sampling locations are fairly well distributed among areas of distinct water quality and circulation regimes, that is to say, more polluted in protected areas and better conditions along/facing the main circulation channel.
During the century-long history of phytoplankton investigations in Guanabara Bay, only five out of the 24 selected studies stand out in terms of new occurrences: the very first inventory (Faria \& Cunha 1917), the monitoring program carried out by FEEMA (Soares et al. 1981) and 3 master thesis monographs (Villac 1990, Santos 2002, Lima 2007). As a result, one can have a false perception that 
the phytoplankton biodiversity has increased throughout the years, despite the overall increase in eutrophication of the system as a whole. From the initial inventory of 124 taxa published in 1917, the subsequent additions in species numbers can be attributed to the use of different sampling and analysis strategies that correspond to two different periods. In the first one, the 39 new occurrences found in Soares et al. (1981) and the 55 found in Villac (1990) were probably due to extensive space-time sampling. In the second period, the total of 75 new occurrences detected as of 2000 are probably due to the use of specific microscopic techniques (refer to Appendix 1 and discussion above) that allowed for the precise identification of some taxa, especially diatoms and small flagellates.

Only 27 species stood out in terms of frequency of occurrence and wider distribution (Table 1): 15 diatoms, 9 dinoflagellates, 1 silicoflagellate, 1 euglenophycean and 1 ebriid. All these species are regarded as common in coastal areas, especially those under estuarine influence (Villac 1990).

The most frequently cited species was the dinoflagellate Scrippsiella trochoidea (46\%), theme of the first publication about its harmful bloom (Faria 1914). Although not widely distributed (present in only $22 \%$ of sampling sites), this is definitely a very important component of the local phytoplankton community because it was often found in high abundances $\left(10^{6}\right.$ cell. $\left.\mathrm{L}^{-1}\right)$ in later studies, especially in more protected areas.

The diatom Skeletonema costatum (Greville) Cleve was the second most cited species (42\%); furthermore, it also showed the most extensive space distribution in the bay (in $85 \%$ of sampling sites). This diatom is regarded in the literature as cosmopolitan (Hasle \& Syvertsen 1997), but recent taxonomic reviews based on ultra-structure and molecular markers indicate that there is high biodiversity within the genus so that what is called $S$. costatum could include one or more of the following species: S. ardens Sarno \& Zingone, S. dohrnii Sarno \& Koistra, S. grethae Zingone \& Sarno, S. grevillei Sarno \& Zingone, S. japonicum Zingone \& Sarno, S. menzelii Guillard, Carpenter \& Reimann, S. potamus (Weber) Hasle, S. pseudocostatum Medlin, S. subslasum (Cleve) Bethge and/or S. costatum itself (Sarno et al. 2007). Further studies are needed to establish the true biodiversity of this abundant and frequently reported genus, not only in Guanabara Bay but also along the Brazilian coast in general.

Among those prominent taxa listed in Table 1, the following ones have been cited as bloom-forming species, some of them as potentially toxic (as stated in Hallegraeff et al. 2003, Fukuyo et al. 1990, Faust \& Gulledge 2002, Odebrecht et al. 2002, Moestrup 2004, Sunesen \& Sar 2007): the diatoms Cerataulina pelagica (Cleve) Hendey, Ceratoneis closterium Ehrenberg, Leptocylindrus danicus Cleve, Leptocylindrus minimus Gran; the dinoflagellates Oxyphysis oxytoxoides Kofoid, Prorocentrum micans Ehrenberg, Prorocentrum triestinum Schiller, Prorocentrum balticum (Lohman) Loeblich; and the silicoflagellate Dictyocha fibula Ehrenberg. Some taxa that did not stand out in terms of overall contribution to the community, but are also worth noting because they have been implicated in serious harmful effects are: the diatoms Asterionellopsis glacialis (Castracane) Round, Chaetoceros coarctatus Lauder, Guinardia delicatula (Cleve) Hasle; the dinoflagellates Akashiwo sanguinea (K. Hirasaka) G. Hansen \& $\emptyset$. Moestrup, Ceratium fusus (Ehrenberg) Dujardin, Ceratium hircus Schröder, Dinophysis acuminata Claparède \& Lachmann, Dinophysis caudata Saville-Kent, Noctiluca scintillans (Macartney) Kofoid \& Swezy; and the cyanobacteria Trichodesmium erythraeum Ehrenberg ex Gomont and Trichodesmium thiebautii Gomont ex Gomont.

The occurrence of the genus Pseudo-nitzschia merits mentioning. This diatom has been frequently found since the first inventory of 1917 (in 54\% of citations) and is also widespread (in 63\% of sampling sites). It was not included in Table 1 because the selecting criterion was based on taxa identified to species level, that is, only the most recent publications that used electron microscopy were capable of precise identification within this genus. From the 37 taxa described, 12 can produce the neurotoxin domoic acid (Villac et al. 2010), of which 5 have already been found in Guanabara Bay: Pseudo-nitzschia cuspidata (Hasle) Hasle, Pseudo-nitzschia delicatissima (Cleve) Heiden in Heiden \& Kolbe, Pseudo-nitzschia fraudulenta (Cleve) Hasle, Pseudo-nitzschia multistriata (Takano) Takano and Pseudo-nitzschia pungens (Grunow ex Cleve) Hasle.

\section{Some Relevant Quali-Quantitative Aspects}

As previously discussed, the historical account of the phytoplankton composition of Guanabara Bay does not reflect the loss of biodiversity expected in highly impacted environments. The reason for this may be twofold: 1) the increasing biodiversity is an artifact caused by our progressively improving capability to detect and identify species and 2) the possible effects of eutrophication could be better perceived when the community structure is evaluated; in other words, when space-time variations in the abundances of the populations (rather than just number of species) are also taken into account.

Guanabara Bay, as an estuarine system, is subjected to natural stress associated with tidal variations that create spatial gradients in key parameters such as temperature, salinity, turbidity, and also nutrient concentrations (Mayr et al. 1989). Seasonal variations in air temperature and rainfall, highest during summertime, influence the local plankton community that can naturally respond with the proliferation of opportunistic species as already observed during the harmful S. trochoidea bloom of 1913. The increase in the organic and chemical loads, attributed to the urban development in the Guanabara Bay watershed that intensified in the 1950's, imposed additional stressors. It is not possible, however, to pinpoint exactly when changes in the phytoplankton community started to be triggered by maninduced interference because ecological studies (quali-quantitative) started to be systematically conducted only in the 1970's.

High abundances of filamentous cyanobacteria have received much attention since the very first quali-quantitative assessments (e.g., Sevrin-Reyssac et al. 1979) and can be interpreted as a response to increasing eutrophication levels. Concentrations that can reach up to $10^{8}$ filaments. $\mathrm{L}^{-1}$ can be found, especially during summer and closer to the surface (Villac 1990). Interestingly, this does not exclude high cell concentrations $\left(10^{6}-10^{7}\right.$ cell. $\left.\mathrm{L}^{-1}\right)$ of other species such as: the diatoms Cyclotella (Kützing) Brébisson spp., C. closterium and S. costatum; the dinoflagellates Prorocentrum spp. and S. trochoidea; and euglenophyceans of the genus Eutreptia Perty (Oliveira 1962, Sevrin-Reyssac et al. 1979, Villac 1990, Santos 2002). Several unidentified nanoflagellates (among chlorophytes, raphidophytes and cryptophytes) are also frequently reported for their high abundances. All these taxa are considered as small organisms, mostly $10-20 \mu \mathrm{m}$ (but a few reaching $30 \mu \mathrm{m}$ ), and can often be regarded as opportunistic.

Total cell numbers show a fairly wide range $\left(10^{5}-10^{9}\right.$ cell. $\left.\mathrm{L}^{-1}\right)$ that can be interpreted as the multiple responses given by the phytoplankton community to environmental conditions that vary both in space and time (Villac 1990, Santos 2002, Lima 2007). A stronger thermohaline gradient takes place especially during the rainy season (summer), when the most contrasting settings are observed. During this period, the highest cell abundances of opportunistic species (small diatoms, flagellates, and cyanobacteria) are detected on the surface and in areas closer to the margins and the inner reaches of the bay. Conversely, closer to the entrance to the bay, especially in deeper waters facing the main circulation channel, lower cell abundances are accompanied by higher biodiversity, particularly of larger diatoms. 
The most polluted region of the bay is a canal on the west margin, between the continent and the Islands of Governador and Fundão (Figure 1). Environmental concern with this region in particular dates back to 1940's due to unstructured urbanization and landfills that altered its circulation pattern (Oliveira 1958). The assessment done in the 1980's (Villac et al. 1991) compared the community structure of this region with that of the main circulation channel that faces the contribution of cleaner waters. The ecological instability of the first was indicated by very low diversity (Shannon-Weaner index: 0.03-1.80 bits.cell ${ }^{-1}$, $50 \%<1.00$ bits.cell $^{-1}$ ), whereas the higher diversity levels of the latter (Shannon-Weaner index: $1.30-3.90$ bits.cell $^{-1}, 35 \%>1.00$ bits.cell $^{-1}$ ) may suggest the presence of a community that is more prone to absorbing disturbances.

In more recent studies (1998-2000), the region closer to Urca was classified as meso-eutrophic and the one closer to Ramos was classified as hypereutrophic (Santos 2002, according to the classification system of Hakanson 1994) (Figure 1). These contrasting trophic states, which are based on total nitrogen and chlorophyll levels, were also detected in the phytoplankton community. Site Urca stood out for a larger contribution of the autotrophic microplankton fraction and higher species numbers than Ramos (respectively, 168 and 69). This difference in trophic state and corresponding effects on the composition and abundance of the phytoplankton populations may have direct implications for energy transfer through the aquatic food web of Guanabara Bay.

\section{Recommendations for Future Studies Focusing Taxonomy}

Taxonomy (and systematics) of microalgae is a very dynamic field. Molecular data, often in association with ultrastructure and aspects of life cycles, has provided valuable data to fuel frequent rearrangements at higher hierarchical levels (Brodie \& Lewis 2007) and to boost our knowledge of biodiversity by revealing cryptic species (e.g., Montresor et al. 2003, Murray et al. 2004, Geisen et al. 2004, Lilly et al. 2007, Sarno et al. 2007, Casteleyn et al. 2008, Vlprey et al. 2008). The use of electron microscopy, although still timid, has already contributed to advance our understanding of the phytoplankton species composition of Guanabara Bay. Molecular data and information about life cycles, however, constitute a gap that merits the attention of researchers and funding agencies, provided that facilities to maintain live material are also available. Our contention is that resources to allow for the study of live material (culture collections) are urgently needed to advance our knowledge about the true biodiversity of the phytoplankton not only of Guanabara Bay but also of the Brazilian coast as a whole.

\section{Acknowledgments}

We are truly grateful to all those researchers who have had the chance to work with the phytoplankton of the still beautiful Guanabara Bay, which made possible our better understanding of its biodiversity. We also thank those who spent uncountable hours on the computer to help us create a "century-long" data base that set the stage for this review.

\section{References}

ADL, S.M., SIMPSON, A.G.B., FARMER, M.A., ANDERSEN, R.A., ANDERSON, O.R., BARTA, J.R., BOWSER, S.S., BRUGEROLLE, G., FENSOME, R.A., FREDERICO, S., JAMES, T.Y., KARPOV, S., KUGRENS, P., KRUG, J., LANE, C.E., LEWIS, L.A., LODGE, J., LYNN, D.H., MANN, D.G., MCCOURT, R.M., MENDOZA, L., MOESTRUP, O, MOZLEY-STANDRIDGE, S.E., NERAD, T.A., SHEARER, C.A., SMIRNOV, A.V., SPIEGEL, F.W. \&. TAYLOR, M.J.R. 2005. The new higher level classification of eukaryotes with emphasis on the taxonomy of protists. J. Eukaryot. Microbiol. 52:399-451.
ANAGNOSTIDIS, K. \& KOMÁREK, J. 1988. Modern approach to the classification system of Cyanophytes. 3 - Oscillatoriales. Algol. Stud. 50-53:327-472.

BALDAUF, S.L. 2003. The deep roots of eukaryotes. Science 300:1703-1706.

BALECH, E. \& SOARES, L.O. 1966. Dos dinoflagelados de la Baía de Guanabara y proximidades (Brasil). Neotropica 12:103-109.

BARBOSA, M.B. \& TENENBAUM, D.R. 1996. A influência da maré na distribuição do fitoplâncton na baía de Guanabara num período de 24h. In IV Congresso Latino Americano de Ficologia, II Reunião Ibero Americana de Ficologia, VII Reunião Brasileira de Ficologia. Sociedade Brasileira de Ficologia, Sociedade Ficológica da América Latina e Caribe, Caxambu, p.64.

BARBOSA, M.B. 1997. A Influência da maré na distribuição do microfitoplâncton na Baía de Guanabara (Rio de Janeiro, RJ). Trabalho de Conclusão de Curso, Universidade Federal Fluminense, Niterói.

BARTH, R. 1972. Observações em nano e ultraplâncton na Baía de Guanabara. Publ. Inst. Pesq. Mar. 68:1-9.

BERGESCH, M., ODEBRECHT, C. \& MOESTRUP, O. 2008. Nanoflagellates from coastal waters in the Southwestern Atlantic $(32 \mathrm{oS})$. Bot. Mar. 51:35-50.

BHATTACHARYA, D., YOON, H.S. \& HACKETT, J.D. 2003. Photosynthetic eukaryotes unite: endosymbiosis connects the dots. BioEssays 26:50-60.

BRAGA, M.R.A. 1980. Estudo comparativo preliminar sobre diatomáceas da comunidade incrustante na baía de Guanabara, Rio de Janeiro, Brasil. Tese de Doutorado, Universidade Santa Úrsula, Rio de Janeiro.

Brasil. Ministério do Planejamento, Orçamento e Gestão. Instituto Brasileiro de Geografia e Estatística - IBGE. 2008. Estimativas populacionais 2008. http://www.ibge.gov.br

BRODIE, J. \& LEWIS, J. 2007. Unravelling the algae. CRC Press, London.

CASTELEYN, G., CHEPURNOV, V.A., LELIAERT, F., MANN, D.G., BATES, S.S., LUNDHOLM, N., RHODES, L., SABBE, K. \& VYVERMAN, W. 2008. Pseudo-nitzschia pungens (Bacillariophyceae): a cosmopolitan diatom species? Harmful Algae 7:241-257.

COELHO, V. 2007. Baía de Guanabara: uma história de agressão ambiental. Casa da Palavra, Rio de Janeiro.

DAUGBJERG, N., HANSEN, G., LARSEN, J. \& MOESTRUP, O. 2000. Phylogeny of some of the major genera of dinoflagellates based on ultrastructure and partial LSU DNA sequence data, including the erection of three new genera of unarmoured dinoflagellates. Phycologia 39:302-317

DIAS, C.T.M., VALLIM, M.A., VALENTIN, J.L., SILVA NETO, I. \& TENENBAUM, D.R. 1998. Distribuição vertical do microfitoplâncton e protozooplâncton da Baía de Guanabara durante um ciclo de maré. In VIII Seminário Regional de Ecologia. Universidade Federal de São Carlos, São Carlos, p.1137-1148.

DREBES, G. 1974. Marines phytoplankton - Eine Auswahl der Helgoländer Planktonalgen. Georg Thieme Verlag, Stuttgart.

FARIA, J.G. 1914. Um ensaio sobre o plankton, seguido de observações sobre occurencia de plankton monotono, causando mortandade entre os peixes na Bahia do Rio de Janeiro. Trabalho de Conclusão de Curso, Universidade Federal do Rio de Janeiro, Rio de Janeiro.

FARIA, J.G., CUNHA, A.M.C. 1917. Estudos sobre o microplâncton da baía do Rio de Janeiro e suas imediações. Mem. Inst. Oswaldo Cruz. 9:68-93.

FAUST, M.A. \& GULLEDGE, R.A. 2002. Identifying harmful marine dinoflagellates. Smithson. Contrib. US Natl. Herb., 42:1-144.

FELDMANN, R.M. \& MANNING, R.B. 1992. Crisis in systematic biology in the age of biodiversity. J. Paleont. 66:157-158.

FENSOME, R.A., TAYLOR, F.J.R., NORRIS, G., SARJEANT, W.A.S., WHARTON, D.I. \& WILLIAMS, G.L. 1993. A classification of living and fossil dinoflagellates. Micropaleontology. Sheridan Press, Hanover. 
GARRIDO, A.M.F., COSTA, H.R. \& BARRETO, M.K. 1978. Avaliação biológica dos pontos críticos da Baía de Guanabara. Cad. FEEMA Ser. Tec. 78: 3356-3365.

GEISEN, M., YOUNG, J.R., PROBERT, I., SÁEZ, A.G., BAUMANN, K.H., BOLLMANN, J., CROS, L., DEVARGAS, C., MEDLIN, L.K. \& SPRENGEL, C. 2004. Species level variation in coccolithophores. In Coccolithophores : from molecular processes to global impact (H.R. Thierstein \& J.R. Young, eds.). Springer, Berlin, p.327-366.

GOMES, E.A.T., CASALI, A.A. \& Silveira, G. 2002. Variações diárias do nanoplâncton auto- e heterotrófico da baía de Guanabara (RJ). In IX Reunião Brasileira de Ficologia. Sociedade Brasileira de Ficologia, Fundação Ecossistemas do Espírito Santo, Santa Cruz, p.196.

GOMES, E.A.T., SANTOS, V.S. \& VILLAC, M.C. 2001a. O protozooplâncton da baía de Guanabara, Brasil. In VIII Congresso Brasileiro de Limnologia. Sociedade Brasileira de Limnologia, Universidade Federal da Paraíba, João Pessoa, p.145.

GOMES, E.A.T., SANTOS, V.S. \& VILLAC, M.C. 2001b. The protozooplankton of Guanabara Bay, Brazil. In Plankton Symposium. Institute of Marine Research, Coimbra, p.141.

GOMES, E.A.T., SANTOS, V.S., TENENBAUM, D.R. \& VILLAC, M.C 2007. Protozooplankton characterization of two contrasting sites in a tropical coastal ecosystem (Guanabara Bay, RJ). Braz. J. Oceanogr. 55:29-38.

GÓMEZ, F. 2005. A list of free-living dinoflagellate species in the world's oceans. Acta Bot. Croat. 64:129-212.

GÓMEZ, F., MOREIRA, D. \& LÓPEZ-GARCÍA, P. 2009. Neoceratium gen. nov., a new genus for all marine species currently assigned to Ceratium (Dinophyceae). Protist 161:35-54.

HÅKANSON, L. 1994. A review of effect-dose-sensitivity models for aquatic ecosystems. Int. Rev. Ges. Hydrobio. 79:621-667.

HASLE, G.R. \& SYVERTSEN, E.E. 1997. Marine diatoms. In Identifying marine phytoplankton (C.R. Tomas, ed.). Academic Press, New York, p.5-385.

HOPPENRATH, M. \& LEANDER, B.S. 2006. Ebriid phylogeny and the expansion of the Cercozoa. Protist 157:279-290.

HULSMAN, J. \& WEISSING, F.J. 1999. Biodiversity of plankton by species oscillations and chaos. Nature 402:407-410.

HUTCHINSON, G.E. 1961. The paradox of the plankton. The American Naturalist 95:137-145.

Japan International Cooperation Agency -- JICA. 1993. The study on recuperation of the Guanabara Bay ecosystem - aquatic organisms. Kokusai Kogyo Co. Ltd., Tokyo, pars 6, p.1-24.

KJERFVE, B., RIBEIRO, C.H.A., DIAS, G.T.M., FILIPPO, A.M. \& QUARESMA, V.S. 1997. Oceanographic characteristics of an impacted coastal bay: Baía de Guanabara, Rio de Janeiro, Brazil. Cont. Shelf Res. 17:609-1643.

KOMÁREK, J. \& ANAGNOSTIDIS, K. 1989. Modern approach to the classification system of Cyanophytes. 4 - Nostocales. Algol. Stud. 56:247-345.

KRAU, L. 1985. Modificações no plâncton da Enseada de Inhauma, antes e depois da poluição. Mem. Inst. Oswaldo Cruz 56:473-476.

LILLY, E.L., HALANYCH, K.M. \& ANDERSON, D.M. 2007. Species boundaries and global biogeography of the Alexandrium tamarense complex (Dinophyceae). J. Phycol. 43:1329-1338.

LIMA, I. V. 2007. Variação em micro-escala temporal do nano e microplâncton da Baía de Guanabara (RJ). Tese de Doutorado, Universidade Federal Fluminense, Niteroi.

LIMA, I.V., TENENBAUM, D.R. \& VALENTIN, J.L. 2006. Influência da maré sobre a abundância e diversidade do fitoplâncton da baía de Guanabara (RJ). In XI Congresso Brasileiro de Ficologia \& Simpósio Latino-Americano Sobre Algas Nocivas. Sociedade Brasileira de Ficologia, Itajaí, p.115.

MATOS, M.C.F.G., SANTOS, V.S. \& VILLAC, M.C. 2002. Composição e distribuição do gênero Pseudo-nitzschia na baía de Guanabara, RJ. In
IX Reunião Brasileira de Ficologia. Sociedade Brasileira de Ficologia e Fundação Ecossistemas do Espírito Santo, Santa Cruz, p.156.

MAYR, L.M., TENENBAUM, D.R. \& VILLAC, M.C. 1989. Hydrobiological characterization of Guanabara bay. In Coastlines of Brazil (O. Magoon \& C. Neves, eds.). American Society of Civil Engineers, New York, p.124-138.

MONTRESOR, M., SGROSSO, S., PROCACCINI, G. \& KOOISTRA, W.H.C.E. 2003. Intraspecific diversity in Scrippsiella trochoidea (Dinophyceae): evidence for cryptic species. Phycologia 42:56-70.

MURRAY, S., JORGENSEN, M.F., DAUGBJERG, N. \& RHODES, L. (2004). Amphidinium revisited. II. Resolving species boundaries in the Amphidinium operculatum species complex (Dinophyceae), including the descriptions of Amphidinium trulla sp. nov. and Amphidinium gibbosum. comb. nov. J. Phycol. 40:366-382.

NORTON, T.A., MELKONIAN, M. \& ANDERSEN, R.A. 1996. Algal biodiversity. Phycologia 35:308-326.

NOT, F., VALENTIN, K., ROMARI, K., LOVEJOY, C., MASSANA, R., TÖBE, K., DANIEL VAULOT, D. \& MEDLIN, L.K. 2006. Picobiliphytes: Aa marine picoplanktonic algal group with unknown affinities to other eukaryotes. Science 315:253-255.

OLIVEIRA, L.P.H. 1947. Distribuição geográfica da fauna e flora da Baía de Guanabara. Mem. Inst. Oswaldo Cruz 45:709-734.

OLIVEIRA, L.P.H. 1958. Poluição das águas marinhas. Estragos na flora e fauna do Rio de Janeiro. Mem. Inst. Oswaldo Cruz 56:39-59.

OLIVEIRA, L.P.H. 1962. Águas com predominância de Eutreptia lanowii Steuer e Chlamydomonas reinhardi Dangeard no plâncton, na enseada de Inhauma, Baía de Guanabara. Mem. Inst. Oswaldo Cruz 60:13-20.

PARANHOS, R., VILLAC, M.C., SUCHAROV, C., MAYR, L.M. \& TENENBAUM, D.R. 1988. Variações de alguns parâmetros bióticos e abióticos em um ponto na Baía de Guanabara (RJ) durante um ciclo de maré. In $40^{\mathrm{a}}$ Reunião Anual da SBPC. Sociedade Brasileira para o Progresso da Ciência, São Paulo, p.702.

PROCOPIAK, L.K., FERNANDES, L.F. \& MOREIRA FILHO, H. 2006. Diatomáceas (Bacillariophyta) marinhas e estuarinas do Paraná, Sul do Brasil: lista de espécies com ênfase em espécies nocivas. Biota Neotropica 6(3): http://www.biotaneotropica.org.br/v6n3/pt/ fullpaper?bn02306032006+pt

REYNOLDS, C.S, PADISÁK, J. \& SOMMER, U. 1993. Intermediate disturbance in the ecology of phytoplankton and the maintenance of species diversity: a synthesis. Hydrobiologia 249:183-188.

Rio de Janeiro (Estado). SECT - Secretaria de Estado de Ciência e Tecnologia SECT 2000. Baía da Guanabara - características ambientais. In Secretaria de Estado de Ciência e Tecnologia (PETROBRAS, org.). SECT, Rio de Janeiro, v. 01, caphap. III3, p.158-161.

ROUND, F.E. Crawford, R.M. \& Mann, D.G. 1990. The diatoms - biology and morphology of the genera. Cambridge University Press, Cambridge.

SANTOS, C.N. \& TENENBAUM, D.R. 1988. Variação sazonal do microfitoplâncton em um ponto fixo na Baía de Guanabara (RJ). In III Encontro Brasileiro de Plâncton. Universidade Federal do Paraná, Curitiba, p.27.

SANTOS,. S. 2002. Nano e microfitoplâncton da Baía de Guanabara (RJ, Brasil) em condições tróficas distintas: aspectos estruturais e préfuncionais. Tese de Doutorado, Universidade Federal do Rio de Janeiro, Rio de Janeiro.

SANTOS, V.S. \& VILLAC, M.C. 2002. "La niña" pode influenciar a estrutura do microplâncton autotrófico da baía de Guanabara (RJ)? In IX Reunião Brasileira de Ficologia. Sociedade Brasileira de Ficologia, Fundação Ecossistemas do Espírito Santo, Santa Cruz, p.183.

SANTOS, V.S. 1999. O Fitoplâncton da Baía de Guanabara (RJ, Brasil): microfitoplâncton autotrófico em dois pontos com qualidade de água diferentes. Tese de Doutorado, Universdade Federal do Rio de Janeiro, Rio de Janeiro.

SANTOS, V.S., PARANHOS, R. \& VILLAC, M.C. 2001. Aplicação de índices de estado trófico na baía de Guanabara associada às respostas do 
microfitoplâncton. In VIII Congresso Basileiro de Limnologia. Sociedade Brasileira de Limnologia, João Pessoa, p.65.

SANTOS, V.S., VILLAC, M.C. \& TENENBAUM, D.R. 1999. O fitoplâncton da Baía de Guanabara (RJ, Brasil): densidade do microfitoplâncton autotrófico em dois pontos com qualidades de água diferentes. In XI Jornada de Iniciação Científica, XXI Jornada de Iniciação Artística e Cultural. Universidade Federal do Rio de Janeiro, Rio de Janeiro. CD-ROM.

SANTOS, V.S., VILLAC, M.C. \& TENENBAUM, D.R. 1999. Qual o verdadeiro microfitoplâncton da baía de Guanabara, RJ, Brasil? In VIII Reunião Brasileira de Ficologia. Universidade Federal de Pernambuco, Recife, p.52.

SANTOS, V.S., VILLAC, M.C. \& TENENBAUM, D.R. 2006. Variações espaciais e temporais do nanoplâncton e das bactérias filamentosas auto- e heterotróficas da baía de Guanabara (RJ - Brasil). In I Congresso Brasileiro de Biologia Marinha 2006. Universidade Federal Fluminense, Niterói, p.272.

SANTOS, V.S., VILLAC, M.C., TENENBAUM, D.R. \& PARANHOS, R. 2007. Auto- and heterotrophic nanoplankton and filamentous bacteria of Guanabara Bay (RJ, Brazil): estimates of cell/filament numbers versus carbon content. Braz. J. Oceanogr. 55:133-143.

SARNO, D., KOOISTRA, W., BALZANO, S., HARGRAVES, P. \& ZINGONE, A. 2007. Diversity in the genus Skeletonema (Bacillariophyceae): III. Phylogenetic position and morphological variability of Skeletonema costatum and Skeletonema grevillei, with the description of Skeletonema ardens sp. nov. J. Phycol. 43:156-170.

SARTHOU, C. 1964. Passado e presente da Baía de Guanabara. Freitas Bastos, Rio de Janeiro.

SCHEFFER, M., RINALDI, S., HUISMAN, J. \& WEISSING, F.J. 2003. Why plankton communities have no equilibrium: solutions to the paradox. Hydrobiologia 491:9-18.

SCHUTZE, M.L.M., MACHADO, M.C. \& ZILLMAN, S.M.S. 1989. Phytoplankton biomass of Guanabara Bay (Rio de Janeiro, Brazil) and adjacent oceanic area: Variations from January through July 1979. In International Symposium on Utilization of Coastal Ecosystems: Planning, Pollution and Productivity (M.R.C. Figueiredo, N.L. Chao \& W.K Smith, eds.). Fundação Universidade Federal do Rio Grande, Rio Grande, v.2., p.309-324.

SEVRIN-REYSSAC, J. 1980. Recherche sur le phytoplancton de la côte bresiliene (aspect qualitatif et quantitatif, biogeographie). Essai de comparaison avec les population de L'Ouest-Africain. Bul. Mus. Natn. Hist. Nat. 4:295-339.

SEVRIN-REYSSAC, J. MACHADO, M.C.S., SCHUTZE, M.L.M., BIBAS, S.G., LIMA, C.A. \& ESTEVES, C.P. 1979. Biomasse et production du phytoplancton de la baie de Guanabara (État de Rio de Janeiro, Brésil) et du secteur océanique adjacent. Variations de mai à juillet 1978. Bul. Mus. Natn. Hist. Nat. 4:329-354.

SILVA, N.M.L., VALENTIN, J.L. \& BASTOS, C.T.B. 1988. O microfitoplâncton das águas costeiras do litoral fluminense (Estado do Rio de Janeiro): lista de espécies e aspectos ecológicos. Bol. Inst. Oceanogr. 36:1-16.

SIMON, N., CRAS, A.-L., FOULON, E. \& LEMÉE, R. 2009. Diversity and evolution of marine phytoplankton. C R Biol 332: 159-170.

SMAYDA, T.J. 1970. The suspension and sinking of phytoplankton in the sea. Oceanogr. Mar. Biol. Ann. Rev. 8:353-414.

SMETACEK,, V. 2001. A watery arms race. Nature 411:745.

SOARES, Z.O., FRANCA, L.B.P. \& UTCHITEL, S. 1981. Fitoplâncton e fatores abióticos na Baía de Guanabara - Rio de Janeiro - subsídios para o controle de poluição. In XI Congresso Brasileiro de Engenharia Sanitária e Ambiental. Cad. FEEMA Ser. Congr., Fortaleza.

SOURNIA, A. 1978. Phytoplankton manual. Unesco, Paris.

SOURNIA, A. 1986. Atlas du phytoplankton marin. Volume I: Introduction, Cyanophycées, Dictyochophycées, Dinophycées et Raphidiophycées. Éditions du Centre National de La Recherche Scientifique, Paris.
SOURNIA, A., CHRETIENNOT-DINET, M.J. \& RICARD, M. 1991. Marine phytoplankton: how many species in the world? J. Plankton Res. 13:1093-1099.

SOUZA, C.A.F., FIGUEIREDO, L.R.A. \& UTCHITEL, S. 1983. Relatório Baía de Guanabara. FEEMA, Rio de Janeiro.

SUNESEN, I. \& SAR, E. A. 2007. Diatomeas marinas de aguas costeras de la provincia de Buenos Aires (Argentina). III Géneros potencialmente nocivos Asterionellopsis, Cerataulina, Ceratoneis y Leptocylindrus. Rev. Chil. Hist. Nat. 80:493-507.

TENENBAUM, D.R. 2002. O que sabemos sobre o fitoplâncton do litoral brasileiro? In Biodiversidade, conservação e uso sustentável da flora do Brasil (E.L. Araujo, A.N. Moura, E. Sampaio, L. Gestinari \& J. Carneiro, orgs.). Imprensa Universitária, v.1, p.109-116.

TENENBAUM, D.R. VILLAC, M.C., GOMES, E.A.T., CUPELO, A.C.G. \& SANTOS, V.S. 2001. A new "sight" on microbial plankton ecology: coastal x oceanic system in Brazil. Oecol. Bras. 9:133-152.

TENENBAUM, D.R., 2006. Dinoflagelados e tintinídeos da região central da Zona Econômica Exclusiva brasileira: guia de identificação. Museu Nacional, Rio de Janeiro.

TENENBAUM, D.R., MARINHO, M.M., GÔMARA, G., VIANA, S.C. \& MATOS, M.C.F.G. 2004a. Fitoplâncton. In A biota da área sob influência do Porto de Sepetiba, Rio de Janeiro, Brasil: levantamento de dados pretéritos (M.C. VILLAC, F.C. FERNANDES, S. JABLONSKI, A.C. LEAL NETO \& B.H. COUTINHO, eds.). Ministério do Meio Ambiente, Brasília, p.13-22.

TENENBAUM, D.R., VILLAC, M.C., SANTOS, V.S. \& GOMES, E.A.T. 1999. O plâncton da baía de Guanabara sob uma nova ótica. In XII Semana Nacional de Oceanografia. Universidade Estadual do Rio de Janeiro, Rio de Janeiro, p.148-150.

TENENBAUM, D.R., VILlAC, M.C., VIANA, S.C., MATOS, M., HATHERLY, M., LIMA, I.V. \& MENEZES, M. 2004b. Phytoplankton atlas of Sepetiba Bay, Rio de Janeiro. IMO, London. (GloBallast Monograph Series, 16).

THRONDSEN, J. 1997. The planktonic marine flagellates. In Identifying marine phytoplankton (C.R. Tomas, ed.). Academic Press, San Diego, p.591-729.

VALENTIN, J. L., TENENBAUM, D.R., NOGUEIRA, C.R., BONECKER, S.L.C. \& VILLAC, M.C. 1997. The plankton of Guanabara bay, Rio de Janeiro, Brazil. A review. In III International Conference on the Environmental Management of Enclosed Coastal Seas. Stockholm, v.1., p.1.

VALENTIN, J.L., TENENBAUM, D.R., BONECKER, A.C.T., BONECKER, S.L.C, NOGUEIRA, C.R., PARANHOS, R. \& VILLAC, M.C. 1999a. Caractéristiques hydrobiologiques de la Baie de Guanabara (Rio de Janeiro, Brésil). J. Rech. Océanogr. 24:33-41.

VALENTIN, J.L., TENENBAUM, D.R., BONECKER, A.C.T., BONECKER, S.L.C, NOGUEIRA, C.R. \& VILLAC, M.C. 1999b. O sistema planctônico da Baía de Guanabara: Síntese do conhecimento. Oecol. Bras. 7:35-59.

VALLIM, M.A. \& MACHADO, M C. 1990. Biomassa e ecologia do fitoplâncton da Baía de Guanabara e região nerítica adjacente. I. Período de julho a dezembro de 1988. In IV Encontro Brasileiro de Plâncton. Universidade Federal de Pernambuco, Recife, p.40-41.

VALLIM, M.A.1995. Influência da maré na variação microfitoplanctônica em área impactada da Baía de Guanabara (Estado do Rio de Janeiro - Brasil). M.S. Dissertation, Universidade Federal Fluminense, Niteroi.

VILLAC, M.C. \& TENENBAUM, D.R. 2001. The coastal Pseudo-nitzschia from the state of Rio de Janeiro, Brazil. In International Conference on Harmful Algal Blooms. Hobart, v.1, p.34-37.

VILLAC, M.C., DOUCETTE, G.J. \& KACZMARSKA, I. (2010). Toxic marine diatoms. In The diatoms, applications for the environmental and earth sciences (J.P. Smoll \& E. Stoermer, eds.), 2 ed. Cambridge University Press, Cambridge., p.536-547.

VILLAC, M.C., MACEDO, M.L.C. \& TENENBAUM, D.R. 1987. O fitoplâncton da Baía de Guanabara, (RJ) Brasil: dinâmica das populações durante um ciclo de maré. In III Reunião Brasileira de Ficologia. Sociedade Brasileira de Ficologia, Arraial do Cabo, p.22. 
VILLAC, M.C., MACEDO, M.L.C., TENENBAUM, D.R., PARANHOS, R. \& MAYR, L.M. 1988a. A influência da maré no fitoplâncton em uma área sob intensa eutrofização na Baía de Guanabara. In III Encontro Brasileiro de Plâncton. Universidade Federal do Paraná, Curitiba, p.33.

VILLAC, M.C., MATOS, M.C F.G., SANTOS, V.S., RODRIGUES, A.W.L. \& VIANA, S.C. 2002. Composition and distribution of Pseudo-nitzschia from Guanabara Bay, Brazil: The role of salinity, based on field and culture observations. In Harmful Algal Blooms (K.A. Steidinger, J.H. Landsberg, C.R. Tomas, \& G.A. Vargo, eds.). Florida, p.56-58.

VILLAC, M.C., MATOS, M.C.F.G. \& COSTA, R.S.M. 2001.Discriminating between potentially toxic and non-toxic diatoms, genus Pseudo-nitzschia, from Guanabara Bay (RJ, Brazil). In XVIII Congress of the Brazillian Society for Microscopy and Microanalysis. Acta Microscópica, Águas de Lindóia, p.211-212.

VILLAC, M.C, MATOS, M.G. SANTOS, V.S., RODRIGUES, A.W.L. \& VIANA, S.C. (2004). Composition and distribution of Pseudo-nitizschia from Guanabara Bay, Brazil: The role of salinity based on field and culture observations. In: Steidinger, K.A., Landsberg, J.H., Tomas, C.R. \& Vargo, G.A.. (eds.), Harmful Algae 2002, p. 56-58, Florida Fish and Wildlife Conservation Comission, Florida Institute of Oceanography, IOC/UNESCO.

VILLAC, M.C., MAYR, L.M., TENENBAUM, D. R. \& PARANHOS, R. 1991. Sampling strategies proposed to monitor Guanabara Bay, RJ, Brazil. In Coastal Zone 1991. Los Angeles, p.1168-1182.

VILLAC, M.C., NORONHA, V.A.P.C. \& PINTO, T.O. 2008. The phytoplankton biodiversity of the coast of the state of São Paulo, Brazil. Biota Neotropica 8:151-173.

VILLAC, M.C., TENENBAUM, D.R. \& FRYXELL, G.A. 1996. Toxic and non-toxic diatoms, genus Pseudo-nitzschia, from Monterey Bay (USA) and from the Rio de Janeiro coast (Brazil). In IV Congresso Latino Americano de Ficologia, II Reunião Ibero Americana de Ficologia e VII Reunião Brasileira de Ficologia. Sociedade Brasileira de Ficologia e Sociedade Ficológica da América Latina e Caribe, Caxambú, v.1, p.203.
VILLAC, M.C., TENENBAUM, D.R. \& VALENTIN, J.L. 1988b. Ciclo anual do fitoplâncton da Baía de Guanabara (RJ): distribuição espaço-temporal durante 1985. In III Encontro Brasileiro de Plâncton. Universidade Federal do Paraná, Curitiba, p.34.

VILLAC, M.C., TENENBAUM, D.R. \& VALENTIN, J.L.1988c. O fitoplâncton da Baía de Guanabara (RJ, Brasil): avaliação preliminar da dinâmica das populações a 5m, durante 1985. In Semana de Debates Científicos. Universidade Federal do Rio de Janeiro, Rio de Janeiro.

VILLAC, M.C. \& TENENBAUM, D.R. (2000). The coastal Pseudo-nitzschia from the state of Rio de Janeiro, Brazil. In 9th International Conference on Harmful Algal Blooms. Hobart, p.241.

VILLAC, M.C. \& TENENBAUM, D.R. (2001). The coastal Pseudo-nitzschia from the state of Rio de Janeiro, Brazil. In: Hallegraeff, G.M., Blackburn, S.I., Bolch, C.J. \& Lewis, R.J. (eds.), Harmful Algal Blooms 2000, p. 34-37. IOC, Paris.

VILLAC, M.C.1990. O fitoplâncton como um instrumento de diagnose e monitoramento ambiental: um estudo de caso da Baía de Guanabara. Tese de Doutorado, Universidade Federal do Rio de Janeiro, Rio de Janeiro.

VLPREY, M., GUILLOU, L., FERRÉOL, M. \& VAULOT, D. 2008. Wide genetic diversity of picoplanktonic green algae (Chloroplastida) in the Mediterranean Sea uncovered by a phylum-biased PCR approach. Environ. Microbiol. 10:1804-1822.

WHITTAKER, R.H. 1969. New concepts of kingdoms or organisms. Evolutionary relations are better represented by new classifications than by the traditional two kingdoms. Science 163: 150-60.

WILSON, E.O. 1988. Biodiversity. National Academy, Washington.

Received 26/09/09

Revised 09/03/10

Accpeted 24/05/10 


\section{Appendix 1.}

Appendix 1. List of phytoplankton studies indicating author(s), date and type of publication, focus, sampling period, methodological approach and other details regarding field and laboratory work. Codes 1 - 57 are used in graph legends in the main text. Type of publication: $\mathrm{J}$ - journal; C - conference; U - bachelors undergraduate monograph; M - MSc monograph; P - PhD monograph; B - book; R - report. Laboratory analysis: LM - light microscopy; SEM - scanning electron microscopy; EF - epifluorescence microscopy. * Selected sources for the detailed discussion about species composition and biodiversity (see text for selecting criteria). nd $=$ not determined.

\begin{tabular}{|c|c|c|c|c|c|c|c|c|c|c|}
\hline \multicolumn{3}{|c|}{ Publication } & \multirow[t]{2}{*}{ Focus } & \multirow{2}{*}{$\begin{array}{l}\text { Sampling } \\
\text { period }\end{array}$} & \multicolumn{5}{|c|}{ methods } & \multirow{2}{*}{$\begin{array}{l}\text { Additional } \\
\text { information }\end{array}$} \\
\hline Code & $\begin{array}{c}\text { Author(s), } \\
\text { date }\end{array}$ & Type & & & Approach & Sites & Sampling & Collector & Analysis & \\
\hline $1 *$ & Faria (1914) & $\mathrm{P}$ & ecology & June 1913 & $\begin{array}{l}\text { quali- } \\
\text { quantitative }\end{array}$ & 1 & $\begin{array}{l}\text { surface, } 1 \mathrm{~m}, 2-3 \mathrm{~m} \\
\text { (close to bottom) }\end{array}$ & net, bottle & $\begin{array}{l}\text { centrifugation; } \\
\text { LM: slides }\end{array}$ & - \\
\hline $2^{*}$ & $\begin{array}{c}\text { Faria \& } \\
\text { Cunha (1917) }\end{array}$ & $\mathrm{J}$ & inventory & $1913-1917$ & qualitative & nd & horizontal tow & net & LM: slides & ciliates \\
\hline 3 & $\begin{array}{c}\text { Oliveira } \\
\text { (1947) }\end{array}$ & $\mathrm{J}$ & $\begin{array}{c}\text { review } \\
\text { (biogeography) }\end{array}$ & - & - & - & - & - & - & - \\
\hline $4^{*}$ & Krau (1958) & $\mathrm{J}$ & inventory & $1918,1944,1958$ & qualitative & nd & - & $?$ & LM: slides & $\begin{array}{l}\text { bacteria, } \\
\text { ciliates, } \\
\text { zooplankton }\end{array}$ \\
\hline $5^{*}$ & $\begin{array}{l}\text { Oliveira } \\
(1962)\end{array}$ & $\mathrm{J}$ & ecology & March, April 1960 & $\begin{array}{l}\text { quali- } \\
\text { quantitative }\end{array}$ & nd & - & $?$ & $\mathrm{LM}$ & - \\
\hline $6^{*}$ & $\begin{array}{c}\text { Balech \& } \\
\text { Soares (1966) }\end{array}$ & $\mathrm{J}$ & taxonomy & nd & qualitative & nd & - & $?$ & LM & - \\
\hline 7 & Barth (1972) & $\mathrm{J}$ & ecology & $\begin{array}{l}\text { June -August 1971, } \\
\text { July-October } 1972\end{array}$ & quantitative & nd & $\begin{array}{l}\text { daily; surface } \& 1.5 \mathrm{~m} \\
\text { from bottom }\end{array}$ & $\begin{array}{c}\text { net } \\
(45 / 65 \mu \mathrm{m})\end{array}$ & Coulter counter & - \\
\hline $8^{*}$ & $\begin{array}{l}\text { Garrido et al. } \\
\text { (1978) }\end{array}$ & $\mathrm{J}$ & ecology & March, October 1976 & $\begin{array}{l}\text { quali- } \\
\text { quantitative }\end{array}$ & 12 & $\begin{array}{c}\text { monthly; surface, } \\
\text { Secchi disk \& bottom }\end{array}$ & bottle & LM: Utermöhl & chlorophyll- $a$ \\
\hline $9^{*}$ & $\begin{array}{l}\text { Sevrin- } \\
\text { Reyssac et al. } \\
\text { (1979) }\end{array}$ & $\mathrm{J}$ & ecology & May-July 1978 & quantitative & 8 & $\begin{array}{c}\text { every } 10 \text { days; surface } \& \\
\text { Secchi disk }\end{array}$ & bottle? & LM: Utermöhl & $\begin{array}{l}\text { primary } \\
\text { production, } \\
\text { chlorophyll- } a\end{array}$ \\
\hline 10 & Braga (1980) & $\mathrm{U}$ & $\begin{array}{l}\text { ecology + } \\
\text { inventory }\end{array}$ & May, October 1979 & $\begin{array}{c}\text { quali- } \\
\text { quantitative }\end{array}$ & 2 & weekly & $\begin{array}{l}\text { settling } \\
\text { panels }\end{array}$ & LM: slides & - \\
\hline 11 & $\begin{array}{l}\text { Sevrin- } \\
\text { Reyssac } \\
(1980)\end{array}$ & $\mathrm{J}$ & $\begin{array}{c}\text { review } \\
\text { (biogeography) }\end{array}$ & - & - & - & - & - & - & - \\
\hline $12^{*}$ & $\begin{array}{l}\text { Soares et al. } \\
\text { (1981) }\end{array}$ & $\mathrm{R}$ & $\begin{array}{l}\text { ecology }+ \\
\text { inventory }\end{array}$ & 1976-1978, 1980 & $\begin{array}{l}\text { quali- } \\
\text { quantitative }\end{array}$ & 19 & $\begin{array}{l}\text { weekly; surface, Secchi } \\
\text { disk \& bottom }\end{array}$ & $\begin{array}{c}\text { net } \\
(37 / 65 \mu \mathrm{m}) \\
\text { bottle }\end{array}$ & LM: Utermöhl & chlorophyll- $a$ \\
\hline $13^{*}$ & $\begin{array}{l}\text { Souza et al. } \\
\text { (1983) }\end{array}$ & $\mathrm{R}$ & ecology & $\begin{array}{c}\text { August } 1980 \text { - August } \\
1982\end{array}$ & $\begin{array}{l}\text { quali- } \\
\text { quantitative }\end{array}$ & nd & monthly & $?$ & $\mathrm{LM}$ & - \\
\hline 14 & $\begin{array}{l}\text { Villac et al. } \\
\text { (1987) }\end{array}$ & $\mathrm{C}$ & ecology & October 1986 & $\begin{array}{l}\text { quali- } \\
\text { quantitative }\end{array}$ & 1 & $\begin{array}{l}\text { every } 3 \text { hours for } 24 \\
\text { hours (spring tide); } \\
\text { surface, } 5,18 \mathrm{~m}\end{array}$ & bottle & LM: Utermöhl & chlorophyll- $a$ \\
\hline 15 & $\begin{array}{l}\text { Paranhos } \\
\text { et al. (1988) }\end{array}$ & $\mathrm{C}$ & ecology & $\begin{array}{c}\text { October 1986; } \\
\text { January, April, July } \\
1987\end{array}$ & quantitative & 1 & $\begin{array}{c}\text { every } 3 \text { hours for } 24 \\
\text { hours (spring tide); } \\
\text { surface, } 5,18 \mathrm{~m}\end{array}$ & bottle & LM: Utermöhl & chlorophyll- $a$ \\
\hline $16^{*}$ & $\begin{array}{c}\text { Santos \& } \\
\text { Tenenbaum } \\
\text { (1988) }\end{array}$ & $\mathrm{C}$ & ecology & $\begin{array}{c}\text { February, May, } \\
\text { August, November } \\
1987\end{array}$ & $\begin{array}{l}\text { quali- } \\
\text { quantitative }\end{array}$ & 1 & $\begin{array}{c}\text { every } 3 \text { hours for } 24 \text { hours } \\
\text { (spring tide); surface, } 5 \text {, } \\
10 \mathrm{~m}\end{array}$ & bottle & LM: Utermöhl & - \\
\hline $17^{*}$ & $\begin{array}{l}\text { Silva et al. } \\
\text { (1988) }\end{array}$ & $\mathrm{J}$ & $\begin{array}{l}\text { ecology }+ \\
\text { inventory }\end{array}$ & $\begin{array}{c}\text { October 1984, } \\
\text { January, March } 1985\end{array}$ & $\begin{array}{c}\text { quali- } \\
\text { quantitative }\end{array}$ & 1 & surface, 5,15 and $30 \mathrm{~m}$ & bottle & LM: Utermöhl & - \\
\hline 18 & $\begin{array}{l}\text { Villac et al. } \\
\text { (1988a) }\end{array}$ & $\mathrm{C}$ & ecology & September 1987 & $\begin{array}{l}\text { quali- } \\
\text { quantitative }\end{array}$ & 2 & $\begin{array}{l}\text { every } 3 \text { hours for } 24 \\
\text { hours (spring tide); } \\
\text { surface }\end{array}$ & bottle & LM: Utermöhl & chlorophyll- $a$ \\
\hline 19 & $\begin{array}{l}\text { Villac et al. } \\
\text { (1988b) }\end{array}$ & $\mathrm{C}$ & ecology & $\begin{array}{c}\text { January-December } \\
1985\end{array}$ & $\begin{array}{c}\text { quali- } \\
\text { quantitative }\end{array}$ & 15 & monthly; $5 \mathrm{~m}$ & bottle & LM: Utermöhl & chlorophyll- $a$ \\
\hline 20 & $\begin{array}{l}\text { Villac et al. } \\
\text { (1988c) }\end{array}$ & $\mathrm{C}$ & ecology & $\begin{array}{c}\text { January-December } \\
1985\end{array}$ & $\begin{array}{l}\text { quali- } \\
\text { quantitative }\end{array}$ & 15 & monthly; $5 \mathrm{~m}$ & bottle & LM: Utermöhl & - \\
\hline 21 & $\begin{array}{l}\text { Mayr et al. } \\
\text { (1989) }\end{array}$ & $\mathrm{J}$ & $\begin{array}{c}\text { review } \\
\text { (management) }\end{array}$ & - & - & - & - & - & - & - \\
\hline $22 *$ & $\begin{array}{l}\text { Schutze et al. } \\
\text { (1989) }\end{array}$ & $\mathrm{J}$ & ecology & January-July 1979 & $\begin{array}{l}\text { quali- } \\
\text { quantitative }\end{array}$ & 8 & every 10 days; surface & bottle & LM: Utermöhl & chlorophyll- $a$ \\
\hline 23 & $\begin{array}{c}\text { Vallim \& } \\
\text { Machado } \\
(1990)\end{array}$ & $\mathrm{C}$ & ecology & July-December 1988 & quantitative & nd & monthly; surface & bottle & LM: Utermöhl & $\begin{array}{l}\text { chlorophyll- } a \text {, } \\
\text { chlorophyll- } c\end{array}$ \\
\hline $24 *$ & $\begin{array}{l}\text { Villac } \\
(1990)\end{array}$ & M & $\begin{array}{l}\text { ecology }+ \\
\text { inventory }\end{array}$ & $\begin{array}{c}\text { January-December } \\
\text { 1985; October 1986, } \\
\text { January, April, July, } \\
\text { September } 1987\end{array}$ & $\begin{array}{l}\text { quali- } \\
\text { quantitative }\end{array}$ & $\begin{array}{l}15 \\
3\end{array}$ & $\begin{array}{l}\text { - 1985: monthly, } 5 \mathrm{~m} \\
\text { - 1986/87: every } 3 \text { hours } \\
\text { for } 24 \text { hours (spring } \\
\text { tide); surface, } 5,18 \mathrm{~m}\end{array}$ & bottle & LM: Utermöhl & chlorophyll- $a$ \\
\hline 25 & $\begin{array}{c}\text { Villac et al. } \\
(1991)\end{array}$ & $\mathrm{J}$ & $\begin{array}{c}\text { review } \\
\text { (management) }\end{array}$ & - & - & - & - & - & - & - \\
\hline
\end{tabular}


Appendix 1. Continued...

\begin{tabular}{|c|c|c|c|c|c|c|c|c|c|c|}
\hline \multicolumn{3}{|c|}{ Publication } & \multirow[t]{2}{*}{ Focus } & \multirow{2}{*}{$\begin{array}{l}\text { Sampling } \\
\text { period }\end{array}$} & \multicolumn{5}{|c|}{ methods } & \multirow{2}{*}{$\begin{array}{l}\text { Additional } \\
\text { information }\end{array}$} \\
\hline Code & $\begin{array}{c}\text { Author(s), } \\
\text { date }\end{array}$ & Type & & & Approach & Sites & Sampling & Collector & Analysis & \\
\hline $26^{*}$ & JICA (1993) & $\mathrm{R}$ & ecology & 1992 & $\begin{array}{l}\text { quali- } \\
\text { quantitative }\end{array}$ & 18 & surface, bottom & bottle & LM & chlorophyll- $a$ \\
\hline $27 *$ & Vallim (1995) & M & $\begin{array}{l}\text { ecology }+ \\
\text { inventory }\end{array}$ & August 1990 & $\begin{array}{l}\text { quali- } \\
\text { quantitative }\end{array}$ & 1 & $\begin{array}{c}\text { every } 3 \text { hours for } \\
24 \text { hours (spring \& neap } \\
\text { tide); surface, bottom }\end{array}$ & bottle & LM: Utermöhl & - \\
\hline 28 & $\begin{array}{l}\text { Barbosa \& } \\
\text { Tenenbaum, } \\
\text { (1996) }\end{array}$ & $\mathrm{C}$ & ecology & August 1990 & $\begin{array}{l}\text { quali- } \\
\text { quantitative }\end{array}$ & 1 & $\begin{array}{c}\text { every } 3 \text { hours for } \\
24 \text { hours (spring } \& \text { neap } \\
\text { tide); surface, } 11,21 \mathrm{~m}\end{array}$ & bottle & LM: Utermöhl & - \\
\hline \multirow[t]{3}{*}{29} & \multirow{3}{*}{$\begin{array}{l}\text { Villac et al. } \\
\text { (1996) }\end{array}$} & \multirow[t]{3}{*}{$\mathrm{C}$} & \multirow[t]{3}{*}{ ecology } & \multirow[t]{3}{*}{ 1985-1987, 1996} & \multirow{3}{*}{$\begin{array}{l}\text { quali- } \\
\text { quantitative }\end{array}$} & 15 & - 1985: monthly, 5 m & \multirow[t]{3}{*}{ bottle } & \multirow[t]{3}{*}{ LM: Utermöhl } & \multirow[t]{3}{*}{-} \\
\hline & & & & & & 1 & $\begin{array}{c}\text { - 1986/87: every } 3 \text { hours } \\
\text { for } 24 \text { hours (spring } \\
\text { tide); surface, } 5,18 \mathrm{~m}\end{array}$ & & & \\
\hline & & & & & & 1 & $\begin{array}{c}\text { - 1996: occasional, } \\
\text { surface }\end{array}$ & & & \\
\hline $30 *$ & $\begin{array}{c}\text { Barbosa } \\
(1997)\end{array}$ & $\mathrm{U}$ & $\begin{array}{l}\text { ecology }+ \\
\text { inventory }\end{array}$ & August 1990 & $\begin{array}{l}\text { quali- } \\
\text { quantitative }\end{array}$ & 1 & $\begin{array}{c}\text { every } 3 \text { hours for } \\
24 \text { hours (spring \& neap } \\
\text { tide); surface, } 11,21 \mathrm{~m}\end{array}$ & bottle & LM: Utermöhl & - \\
\hline 31 & $\begin{array}{l}\text { Valentin et al. } \\
\qquad(1997)\end{array}$ & $\mathrm{C}$ & $\begin{array}{c}\text { review } \\
\text { (biogeography) }\end{array}$ & - & - & - & - & - & - & - \\
\hline $32 *$ & $\begin{array}{l}\text { Dias et al. } \\
\text { (1998) }\end{array}$ & $\mathbf{J}$ & ecology & September 1995 & $\begin{array}{l}\text { quali- } \\
\text { quantitative }\end{array}$ & 1 & $\begin{array}{c}\text { every } 3 \text { for } 12 \text { hours } \\
\text { (spring tide); surface, } \\
10,20 \mathrm{~m}\end{array}$ & bottle & LM: Utermöhl & ciliates \\
\hline 33 & $\begin{array}{l}\text { Santos et al. } \\
\text { (1999a) }\end{array}$ & $\mathrm{C}$ & ecology & July 1998-July 1999 & $\begin{array}{l}\text { quali- } \\
\text { quantitative }\end{array}$ & 2 & weekly; surface & bottle & $\begin{array}{l}\mathrm{LM}+\mathrm{EF}: \\
\text { Utermöhl }\end{array}$ & - \\
\hline 34 & $\begin{array}{l}\text { Santos et al. } \\
\text { (1999b) }\end{array}$ & $\mathrm{C}$ & ecology & July 1998-July 1999 & $\begin{array}{l}\text { quali- } \\
\text { quantitative }\end{array}$ & 2 & weekly; surface & bottle & $\begin{array}{l}\mathrm{LM}+\mathrm{EF}: \\
\text { Utermöhl }\end{array}$ & - \\
\hline 35 & $\begin{array}{l}\text { Santos } \\
(1999)\end{array}$ & $\mathrm{U}$ & $\begin{array}{l}\text { ecology }+ \\
\text { inventory }\end{array}$ & $\begin{array}{c}\text { July-December } 1997, \\
\text { July 1998-July } 1999\end{array}$ & $\begin{array}{l}\text { quali- } \\
\text { quantitative }\end{array}$ & 2 & weekly; surface & bottle & $\begin{array}{l}\text { LM + EF: } \\
\text { Utermöhl; } \\
\text { biovolume in } \\
\text { carbon }\end{array}$ & - \\
\hline 36 & $\begin{array}{l}\text { Tenenbaum } \\
\text { et al. (1999) }\end{array}$ & $\mathrm{C}$ & ecology & $\begin{array}{c}\text { July } 1998 \text {-January } \\
1999\end{array}$ & $\begin{array}{l}\text { quali- } \\
\text { quantitative }\end{array}$ & 2 & weekly; surface & bottle & $\begin{array}{l}\text { LM + EF: } \\
\text { slides, } \\
\text { Utermöhl }\end{array}$ & - \\
\hline $37 *$ & $\begin{array}{l}\text { Valentin et al. } \\
\qquad(1999 a)\end{array}$ & $\mathbf{J}$ & ecology & May 1992, June 1992 & $\begin{array}{l}\text { quali- } \\
\text { quantitative }\end{array}$ & 18 & $\begin{array}{c}\text { at low } \& \text { high tides; } \\
\text { surface }\end{array}$ & bottle & LM & chlorophyll- $a$ \\
\hline 38 & $\begin{array}{l}\text { Valentin et al. } \\
\qquad(1999 b)\end{array}$ & $\mathrm{J}$ & $\begin{array}{c}\text { review } \\
\text { (biogeography) }\end{array}$ & - & - & - & - & - & - & - \\
\hline 39 & $\begin{array}{l}\text { SECT } \\
(2000)\end{array}$ & $\mathrm{R}$ & $\begin{array}{c}\text { review } \\
\text { (management) }\end{array}$ & - & - & 25 & - & - & - & - \\
\hline \multirow[t]{3}{*}{40} & \multirow{3}{*}{$\begin{array}{c}\text { Villac \& } \\
\text { Tenenbaum } \\
\text { (2000) }\end{array}$} & \multirow[t]{3}{*}{$\mathrm{C}$} & \multirow[t]{3}{*}{ ecology } & 1985 & \multirow[t]{3}{*}{$\begin{array}{l}\text { quali- } \\
\text { quantitative }\end{array}$} & 15 & - 1985: monthly, 5 m & \multirow{3}{*}{$\begin{array}{l}\text { net }(20 \mu \mathrm{m}), \\
\text { bottle }\end{array}$} & \multirow[t]{3}{*}{$\begin{array}{l}\text { LM: slides, } \\
\text { Utermöhl. MEV }\end{array}$} & \multirow[t]{3}{*}{-} \\
\hline & & & & $1986-1987$ & & 1 & $\begin{array}{l}\text { - 1986/87: every } 3 \text { hours } \\
\text { for } 24 \text { hours (spring } \\
\text { tide); surface, } 5,18 \mathrm{~m}\end{array}$ & & & \\
\hline & & & & 1998-1999 & & 2 & $\begin{array}{l}\text { - 1998/99: weekly; } \\
\text { surface }\end{array}$ & & & \\
\hline 41 & $\begin{array}{l}\text { Gomes et al. } \\
\text { (2001a) }\end{array}$ & $\mathrm{C}$ & ecology & $\begin{array}{c}\text { January-December } \\
2000\end{array}$ & $\begin{array}{l}\text { quali- } \\
\text { quantitative }\end{array}$ & 2 & every 15 days; surface & bottle & $\begin{array}{l}\mathrm{LM}+\mathrm{EF}: \\
\text { Utermöhl }\end{array}$ & ciliates \\
\hline $42 *$ & $\begin{array}{l}\text { Gomes et al. } \\
\text { (2001b) }\end{array}$ & $\mathrm{C}$ & ecology & $\begin{array}{c}\text { January-December } \\
2000\end{array}$ & $\begin{array}{l}\text { quali- } \\
\text { quantitative }\end{array}$ & 2 & every 15 days; surface & bottle & $\begin{array}{l}\text { LM + EF: } \\
\text { Utermöhl }\end{array}$ & ciliates \\
\hline 43 & $\begin{array}{l}\text { Santos et al. } \\
\quad(2001)\end{array}$ & $\mathrm{C}$ & ecology & $\begin{array}{c}\text { January } \\
\text { 1998-December } 2000\end{array}$ & $\begin{array}{l}\text { quali- } \\
\text { quantitative }\end{array}$ & 2 & weekly; surface & bottle & LM: Utermöhl & chlorophyll- $a$ \\
\hline 44 & $\begin{array}{l}\text { Tenenbaum } \\
\text { et al. }(2001)\end{array}$ & $\mathrm{J}$ & ecology & $\begin{array}{c}\text { July 1998-January } \\
1999\end{array}$ & quantitative & 2 & weekly; surface & $\begin{array}{l}\text { net }(20 \mu \mathrm{m}) \text {, } \\
\text { bottle }\end{array}$ & $\begin{array}{c}\mathrm{LM}+\mathrm{EF} \text { : } \\
\text { Utermöhl; } \\
\text { biovolume in } \\
\text { carbon }\end{array}$ & - \\
\hline 45 & $\begin{array}{l}\text { Villac et al. } \\
\text { (2001) }\end{array}$ & $\mathrm{C}$ & taxonomy & $\begin{array}{c}\text { July 1998-December } \\
2000\end{array}$ & qualitative & 2 & weekly; surface & $\begin{array}{l}\text { net }(20 \mu \mathrm{m}), \\
\text { bottle }\end{array}$ & $\begin{array}{l}\text { LM: slides, } \\
\text { Utermöhl. } \\
\text { MEV }\end{array}$ & - \\
\hline \multirow[t]{3}{*}{$46 *$} & \multirow{3}{*}{$\begin{array}{l}\text { Villac \& } \\
\text { Tenenbaum } \\
\text { (2001) }\end{array}$} & \multirow[t]{3}{*}{$\mathrm{C}$} & \multirow[t]{3}{*}{ ecology } & 1985 & quali- & 15 & - 1985: monthly, 5 m & \multirow{3}{*}{$\begin{array}{l}\text { net }(20 \mu \mathrm{m}), \\
\text { bottle }\end{array}$} & \multirow{3}{*}{$\begin{array}{l}\text { LM: slides, } \\
\text { Utermöhl. } \\
\text { MEV }\end{array}$} & \multirow[t]{3}{*}{-} \\
\hline & & & & $1986-1987$ & quantitative & 1 & $\begin{array}{c}\text { - 1986/87: every } 3 \text { hours } \\
\text { for } 24 \text { hours (spring tide); } \\
\text { surface, } 5,18 \mathrm{~m}\end{array}$ & & & \\
\hline & & & & 1998-1999 & & 2 & $\begin{array}{c}\text { - 1998/99: weekly; } \\
\text { surface }\end{array}$ & & & \\
\hline
\end{tabular}


Villac, M.C. \& Tenenbaum, D.R.

Appendix 1. Continued...

\begin{tabular}{|c|c|c|c|c|c|c|c|c|c|c|}
\hline \multicolumn{3}{|c|}{ Publication } & \multirow[t]{2}{*}{ Focus } & \multirow{2}{*}{$\begin{array}{l}\text { Sampling } \\
\text { period }\end{array}$} & \multicolumn{5}{|c|}{ methods } & \multirow{2}{*}{$\begin{array}{l}\text { Additional } \\
\text { information }\end{array}$} \\
\hline Code & $\begin{array}{c}\text { Author(s), } \\
\text { date }\end{array}$ & Type & & & Approach & Sites & Sampling & Collector & Analysis & \\
\hline 47 & $\begin{array}{l}\text { Gomes et al. } \\
(2002)\end{array}$ & $\mathrm{C}$ & ecology & April, May 2001 & $\begin{array}{c}\text { quali- } \\
\text { quantitative }\end{array}$ & 1 & daily; surface, $30 \mathrm{~m}$ & bottle & $\begin{array}{l}\mathrm{LM}+\mathrm{EF}: \\
\text { slides }\end{array}$ & - \\
\hline 48 & $\begin{array}{l}\text { Matos et al. } \\
\text { (2002) }\end{array}$ & $\mathrm{C}$ & ecology & $\begin{array}{c}\text { July 1998-December } \\
2000\end{array}$ & $\begin{array}{l}\text { quali- } \\
\text { quantitative }\end{array}$ & 2 & - & $\begin{array}{c}\text { net }(20 \mu \mathrm{m}), \\
\text { bottle }\end{array}$ & $\begin{array}{l}\text { LM: slides, } \\
\text { Utermöhl. } \\
\text { MEV }\end{array}$ & - \\
\hline 49 & $\begin{array}{c}\text { Santos \& } \\
\text { Villac (2002) }\end{array}$ & $\mathrm{C}$ & ecology & $\begin{array}{c}\text { July 1998-December } \\
2000\end{array}$ & $\begin{array}{c}\text { quali- } \\
\text { quantitative }\end{array}$ & 2 & weekly & bottle & LM: Utermöhl & - \\
\hline $50 *$ & $\begin{array}{l}\text { Santos } \\
(2002)\end{array}$ & M & $\begin{array}{l}\text { ecology }+ \\
\text { inventory }\end{array}$ & $\begin{array}{c}\text { July 1998-December } \\
2000\end{array}$ & $\begin{array}{l}\text { quali- } \\
\text { quantitative }\end{array}$ & 2 & weekly; surface & $\begin{array}{c}\text { net }(20 \mu \mathrm{m}), \\
\text { bottle }\end{array}$ & $\begin{array}{c}\mathrm{LM}+\mathrm{EF} \text { : } \\
\text { Utermöhl, } \\
\text { biovolume in } \\
\text { carbon }\end{array}$ & - \\
\hline 51 & $\begin{array}{l}\text { Villac et al. } \\
2002\end{array}$ & $\mathrm{C}$ & ecology & $\begin{array}{c}\text { July 1998-December } \\
2000\end{array}$ & $\begin{array}{c}\text { quali- } \\
\text { quantitative }\end{array}$ & 2 & weekly; surface & $\begin{array}{c}\text { net }(20 \mu \mathrm{m}), \\
\text { bottle }\end{array}$ & $\begin{array}{l}\text { LM: slides, } \\
\text { Utermöhl. } \\
\text { MEV }\end{array}$ & - \\
\hline $52 *$ & $\begin{array}{l}\text { Villac et al. } \\
\text { (2004) }\end{array}$ & $\mathrm{J}$ & ecology & $\begin{array}{c}\text { July 1998-December } \\
2000\end{array}$ & $\begin{array}{l}\text { quali- } \\
\text { quantitative }\end{array}$ & 2 & weekly; surface & $\begin{array}{c}\text { net }(20 \mu \mathrm{m}), \\
\text { bottle }\end{array}$ & $\begin{array}{c}\text { LM: slides, } \\
\text { Utermöhl. } \\
\text { MEV }\end{array}$ & - \\
\hline $53 *$ & $\begin{array}{l}\text { Lima et al. } \\
\qquad(2006)\end{array}$ & $\mathrm{C}$ & ecology & February 2004 & $\begin{array}{l}\text { quali- } \\
\text { quantitative }\end{array}$ & 1 & $\begin{array}{c}\text { every } 3 \text { hours for } \\
72 \text { hours; surface, } 20 \mathrm{~m}\end{array}$ & bottle & LM: Utermöhl & - \\
\hline 54 & $\begin{array}{l}\text { Santos et al. } \\
\text { (2006) }\end{array}$ & $\mathrm{C}$ & ecology & $\begin{array}{c}\text { January-December } \\
2000\end{array}$ & $\begin{array}{l}\text { quali- } \\
\text { quantitative }\end{array}$ & 2 & weekly; surface & bottle & $\begin{array}{c}\mathrm{LM}+\mathrm{EF}: \\
\text { slides, } \\
\text { biovolume in } \\
\text { carbon }\end{array}$ & - \\
\hline $55^{*}$ & $\begin{array}{c}\text { Lima } \\
(2007)\end{array}$ & M & $\begin{array}{l}\text { ecology }+ \\
\text { inventory }\end{array}$ & February 2004 & $\begin{array}{l}\text { quali- } \\
\text { quantitative }\end{array}$ & 1 & $\begin{array}{c}\text { every } 3 \text { hours for } \\
72 \text { hours; surface, } 20 \mathrm{~m}\end{array}$ & bottle & $\begin{array}{l}\text { LM + EF: } \\
\text { Utermöhl }\end{array}$ & - \\
\hline 56 & $\begin{array}{l}\text { Santos et al. } \\
\text { (2007) }\end{array}$ & $\mathrm{J}$ & ecology & $\begin{array}{c}\text { January-December } \\
2000\end{array}$ & $\begin{array}{l}\text { quali- } \\
\text { quantitative }\end{array}$ & 2 & weekly; surface & bottle & $\begin{array}{c}\text { LM + EF: } \\
\text { slides, } \\
\text { biovolume in } \\
\text { carbon }\end{array}$ & - \\
\hline 57 & $\begin{array}{c}\text { Gomes et al. } \\
2007\end{array}$ & $\mathrm{~J}$ & ecology & $\begin{array}{c}\text { January-December } \\
2000\end{array}$ & $\begin{array}{c}\text { quali- } \\
\text { quantitative }\end{array}$ & 2 & weekly; surface & bottle & $\begin{array}{l}\text { LM + EF: } \\
\text { Utermöhl }\end{array}$ & ciliates \\
\hline
\end{tabular}




\title{
Appendix 2.
}

Appendix 2. List of taxa found in Guanabara Bay between 1913 and 2004. The following classification systems were adopted: Round et al. (1990) and Hasle \& Syvertsen (1997) for diatoms (Bacillariophyta); Fensome et al. (1993) for dinoflagellates (Dinoflagellata); Throndsen (1997) for euglenophyceans, prasinophyceans and chlorophyceans (included in Chlorophyta), as well as silicoflagellates (included in Chromophyta); Komárek \& Anagnostidis (1989) and Anagnostidis \& Komárek (1988) for cyanobacteria (Cyanophyta). Two species of the Order Ebriidae (Phylum Sarcomastigophora) are also included in this inventory and follow the classification of Lee et al. (1987 in Throndsen 1997).

\author{
BACILLARIOPHYTA \\ Class Coscinodiscophyceae \\ Order Thalassiosirales \\ Family Thalassiosiraceae \\ Thalassiosira decipiens (Grunow) Jorgensen \\ Thalassiosira cf. gravida Cleve \\ Thalassiosira cf. hyalina (Grunow) Gran \\ Thalassiosira leptopus (Grunow in Van Heurck) Hasle \& Fryxell \\ Thalassiosira lineata Jousé \\ Thalassiosira cf. minuscula Krasske \\ Thalassiosira rotula Meunier \\ Thalassiosira subtilis (Ostenfeld) Gran \\ Family Skeletonemataceae \\ Skeletonema costatum (Greville) Cleve \\ Detonula pumilla (Castracane) Gran \\ Detonula schroederi Bergon \\ Family Stephanodiscaceae \\ Cyclotella litoralis Lange \& Syvertsen \\ Cyclotella meneghiniana Kützing \\ Cyclotella striata Kützing \\ Family Lauderiaceae \\ Lauderia annulata Cleve \\ Order Melosirales \\ Family Melosiraceae \\ Melosira borreri Greville \\ Melosira moniliformis (O. F. Müller) Agardh \\ Melosira nummuloides Agardh \\ Family Hyalodiscaceae \\ Margaritum tenebro (Leuduger-Fortmorel) H. Moreira Filho \\ Family Stephanopyxidaceae \\ Stephanopyxis appendicula (Ehrenberg) Ehrenberg \\ Stephanopyxis apiculata (Ehrenberg) Ehrenberg \\ Stephanopyxis palmeriana (Greville) Grunow \\ Order Paraliales \\ Stephanopyxis turris (Greville \& Arnott) Ralfs \\ Family Paraliaceae \\ Paralia sulcata (Ehrenberg) Cleve \\ Order Coscinodiscales \\ Family Coscinodiscaceae \\ Coscinodiscus centralis Ehrenberg \\ Coscinodiscus excentricus Ehrenberg \\ Coscinodiscus gigas Ehrenberg \\ Coscinodiscus granii Gough \\ Coscinodiscus marginatus Ehrenberg \\ Coscinodiscus nitidus Gregory \\ Coscinodiscus oculus-iridis Ehrenberg \\ Coscinodiscus perforatus Ehrenberg \\ Coscinodiscus perforatus var. pavillardi (Forti) Hustedt \\ Coscinodiscus radiatus Ehrenberg
}


Coscinodiscus radiatus var. media Grunow

Coscinodiscus rothii Grunow

Coscinodiscus vigilans A. Schmidt

Family Hemidiscaceae

Hemidiscus cuneiformis Wallich

Family Heliopeltaceae

Actinoptychus senarius (Ehrenberg) Ehrenberg

Actinoptychus vulgaris Schumann

Order Asteroplamprales

Family Asterolampraceae

Asteromphalus flabellatus (Brébisson) Greville

Order Triceratiales

Family Triceratiaceae

Triceratium favus Ehrenberg

Triceratium reticulum Ehrenberg

Odontella aurita (Lyngbye) Agardh

Odontella mobiliensis (Bailey) Grunow

Odontella obtusa Kützing

Odontella rhombus (Ehrenberg) W. Smith

Odontella sinensis (Greville) Grunow

Cerataulus laevis Ehrenberg

Cerataulus smithii Ralfs ex Pritchard

Family Plagiogrammaceae

Dimeregramma marinum (Gregory) Ralfs

Order Biddulphiales

Family Biddulphiaceae

Biddulphia alternans (Bailey) Van Heurck

Biddulphia biddulphiana (Smith) Boyer

Biddulphia favus (Ehrenberg) H. Van Heurck.

Biddulphia pulchella Gray

Biddulphia tridens (Ehrenberg) Ehrenberg

Isthmia nervosa Kützing

Isthmia obliquata (Smith) C. Agardh

Trigonium alternans (Bailey) Mann

Order Hemiaulales

Family Hemiaulaceae

Hemiaulus hauckii Grunow

Hemiaulus indicus Karsten

Hemiaulus membranaceus Cleve

Hemiaulus sinensis Cleve

Eucampia cornuta (Cleve) Grunow

Eucampia zodiacus Ehrenberg

Climacodium biconcavum Cleve

Climacodium frauenfeldianum Grunow

Cerataulina bicornis (Ehrenberg) Hasle

Cerataulina pelagica (Cleve) Hendey

Order Lithodesmiales

Family Lithodesmiaceae

Lithodesmiun undulatum Ehrenberg

Ditylum brightwellii (T. West) Grunow

Helicotheca tamensis (Shrubsole) Ricard 
Appendix 2. Continued...

Order Corethrales

Family Corethraceae

Corethron pennatum (Grunow) Ostenfeld

Order Rhizosoleniales

Family Rhizosoleniaceae

Dactyliosolen fragilissimus (Bergon) Hasle

Dactyliosolen phuketensis (Sundström) Hasle

Guinardia cylindrus (Cleve) Hasle

Guinardia delicatula (Cleve) Hasle

Guinardia flaccida (Castracane) H. Peragallo

Guinardia striata (Stolterfoth) Hasle

Neocalyptrella robusta (Norman ex Ralfs) Hernández-Becerril \& Meave del Castillo

Proboscia alata (Brightwell) Sundström

Proboscia indica (Peragallo) Hernández-Becerril

Pseudosolenia calcar-avis (Schultze) Sundström

Rhizosolenia acuminata (H. Peragallo) H. Peragallo in H. \& M. Peragallo

Rhizosolenia americana Ehrenberg

Rhizosolenia amputata Ostenfeld

Rhizosolenia annulata Karstein

Rhizosolenia debyana $\mathrm{H}$. Peragallo

Rhizosolenia hebetata Bailey

Rhizosolenia hebetata f. semispina (Hensen) Gran

Rhizosolenia hyalina Ostenfeld in Ostenfeld \& Schmidt

Rhizosolenia imbricata Brigthwell

Rhizosolenia pungens Cleve-Euler

Rhizosolenia rhombus Karsten

Rhizosolenia setigera Brightwell

Rhizosolenia shrubsolei Cleve

Rhizosolenia cf. simplex Karsten

Rhizosolenia styliformis Brightwell

Order Chaetocerotales

Family Chaetocerotaceae

Bacteriastrum delicatulum Cleve

Bacteriastrum furcatum Shadbolt

Bacteriastrum hyalinum Lauder

Chaetoceros affinis Lauder

Chaetoceros brevis Schütt

Chaetoceros cf. ceratosporus Ostenfeld

Chaetoceros coarctatus Lauder

Chaetoceros compressus Lauder

Chaetoceros contortum Shuett

Chaetoceros costatus Pavillard

Chaetoceros curvisetus Cleve

Chaetoceros danicus Cleve

Chaetoceros decipiens Cleve

Chaetoceros didymus var. anglica (Grunow) Gran

Chaetoceros didymus var. didymus Ehrenberg

Chaetoceros didymus var. genuina Gran

Chaetoceros laciniosus Schütt

Chaetoceros laevis Leuduger \& Fortmorel

Chaetoceros lorenzianus Grunow

Chaetoceros pelagicum Cleve 


$$
\begin{aligned}
& \text { Chaetoceros peruvianus Brightwell } \\
& \text { Chaetoceros pseudocurvisetus Mangin } \\
& \text { Chaetoceros schmidtii Ostenfeld } \\
& \text { Chaetoceros schuetii Cleve } \\
& \text { Chaetoceros similis Cleve } \\
& \text { Chaetoceros simplex Ostenfeld } \\
& \text { Chaetoceros teres Cleve }
\end{aligned}
$$

Family Attheyaceae

Attheya septentrionalis (Østrup) Crawford

Order Leptocylindrales

Family Leptocylindraceae

$$
\begin{aligned}
& \text { Leptocylindrus danicus Cleve } \\
& \text { Leptocylindrus mediterraneus (H. Peragallo) Hasle } \\
& \text { Leptocylindrus minimus Gran }
\end{aligned}
$$

Class Fragilariophyceae

Order Fragilariales

Family Fragilariaceae

Asterionellopsis glacialis (Castracane) Round

Synedra tabulata var. acuminata (Agardh) Kutzing

Order Licmophorales

Family Licmophoraceae

Licmophora lyngbyei (Kutzing) Grunow ex Van Heurck

Order Rhaphoneidales

Family Rhaphoneidaceae

Delphineis surirella (Ehrenberg) Andrews

Rhaphoneis cf. nitida (Gregory) Grunow

Order Thalassionemataceae

Family Thalassionemataceae

Thalassionema bacillare (Heinden in Heinden \& Kolbe) Kolbe

Thalassionema frauenfeldii (Grunow) Hallegraeff

Thalassionema nitzschioides (Grunow) Mereschkowsky

Thalassiotrix gibberula Hasle

Thalassiotrix cf. longissima Cleve \& Gronow

Lioloma pacificum (Cupp) Hasle

Family Rhabdonematales

Rhabdonema adriaticum Kützing

Order Striatellales

Family Striatellaceae

Grammatophora marina (Lyngbye) Kützing

Grammatophora oceanica (Ehrenberg) Grunow

Class Bacillariophyceae

Order Lyrellales

Family Lyrellaceae

$$
\begin{aligned}
& \text { Lyrella atlantica (Schmidt) Mann } \\
& \text { Lyrella clavata (Gregory) Mann } \\
& \text { Lyrella lyra (Ehrenberg) Karajeva }
\end{aligned}
$$

Order Cymbellales

Family Anomoeoneidaceae

$$
\text { Staurophora cf. elata (Hustedt ex Simonsen) Mann }
$$

Order Achnanthales

Family Achnanthaceae 
Family Cocconeidaceae

Cocconeis disrupta var. flexella (Jan \& Rabh) Grunow

Cocconeis cf. disruptoides Hustedt

Cocconeis cf. distans Gregory

Cocconeis cf. grata Schmidt

Cocconeis cf. lyra Schmidt

Cocconeis cf. nummularia (Greville) Peragallo

Cocconeis scutellum Ehrenberg

Order Naviculales

Family Diploneidaceae

Diploneis cf. bombus Ehrenberg

Diploneis bombus var. bombiformis (Cleve) Hustedt

Diploneis didyma Ehrenberg

Diploneis cf. suborbicularis (Gregory) Cleve

Family Naviculaceae

Navicula distans (W. Smith) Ralfs in Pritchard

Navicula cf. peregrina (Ehrenberg) Kutzing

Navicula punctata var. coarctata Grunow

Navicula punctata var. elongata Hassall

Navicula cf. socialis Gregory

Navicula spathula Brébisson ex W.Smith

Navicula spathula var. hyalina (Gregory) Grunow

Navicula transitrans var. derasa f. delicatula Heimdal

Navicula cf. triblionella var. levidensis (W. Smith) Grunow

Haslea wawrikae (Hustedt) Simonsen

Haslea cf. trompii (Cleve) Simonsen

Family Pleurosigmataceae

Pleurosigma acuminatum (Kützing) Grunow

Pleurosigma cf. diverse-striatum Meister

Pleurosigma elongatum W. Smith

Pleurosigma naviculaceum Brébisson

Pleurosigma normanii Ralfs in Pritchard

Gyrosigma balticum (Ehrenberg) Rabenhorst

Gyrosigma fasciola (Ehrenberg) Griffith \& Henfrey

Family Plagiotropidaceae

Plagiotropis lepidoptera (Gregory) Kuntze

Order Thalassiophysales

Family Catenulaceae

Amphora acuta Gregory

Amphora cf. angusta Gregory

Amphora exigua Gregory

Amphora cf. fluminensis Grunow

Amphora marina (Castracane) Desikachary \& Prema

Order Bacillariales

Family Bacillariaceae

Bacillaria paxillifera (O. F. Müller) Hendey

Ceratoneis closterium Ehrenberg

Fragilariopsis doliolus (Wallich) Medlin \& Sims

Nitzschia constricta (Gregory) Grunow

Nitzschia longissima (Brébisson in Kützing) Ralfs in Pritchard

Nitzschia sigma (Kützing) W. Smith

Nitzschia lorenziana var. subtilis Grunow 
Appendix 2. Continued...

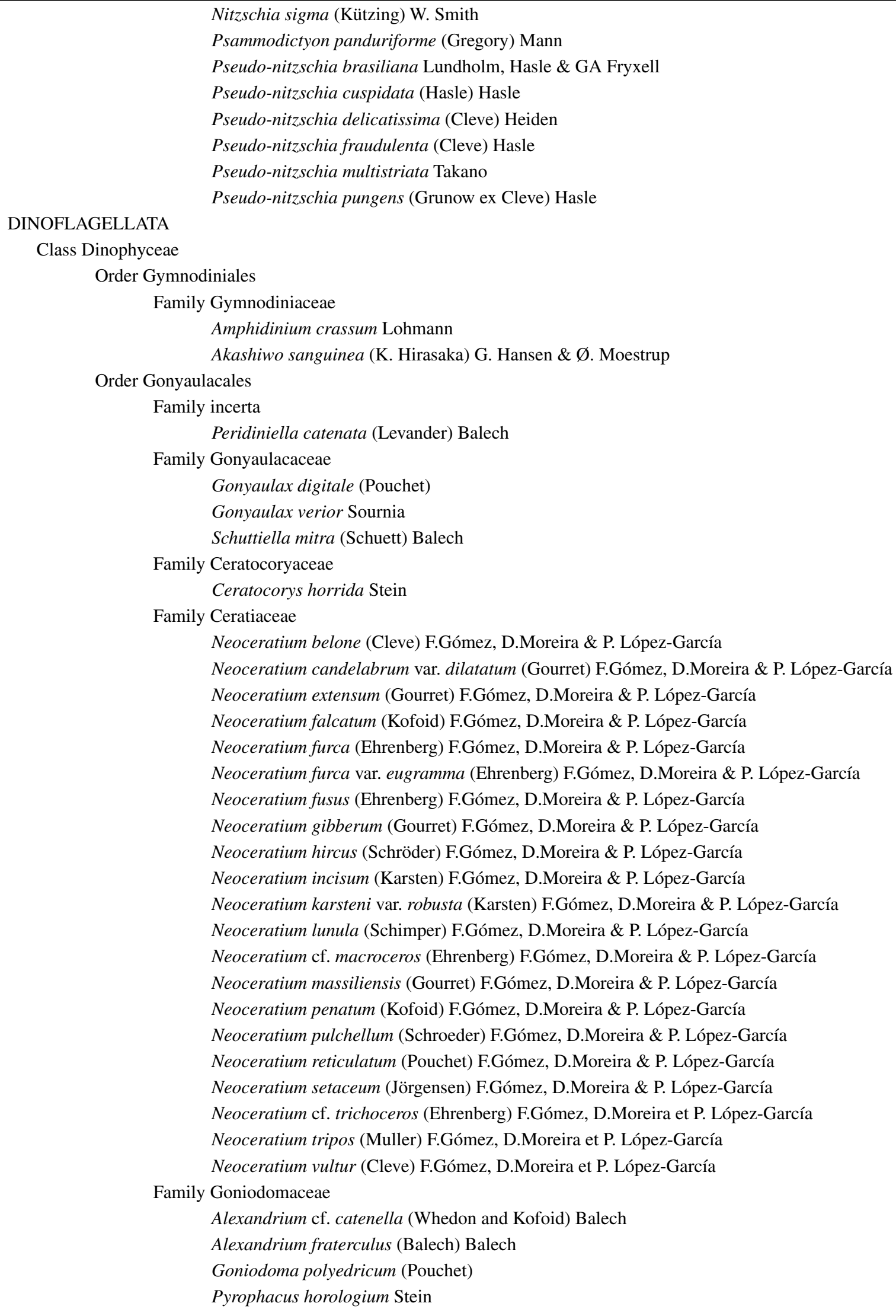

Family Pyrocystaceae

Pyrocystis cf. fusiformis W. Thomson ex Murray 
Appendix 2. Continued...

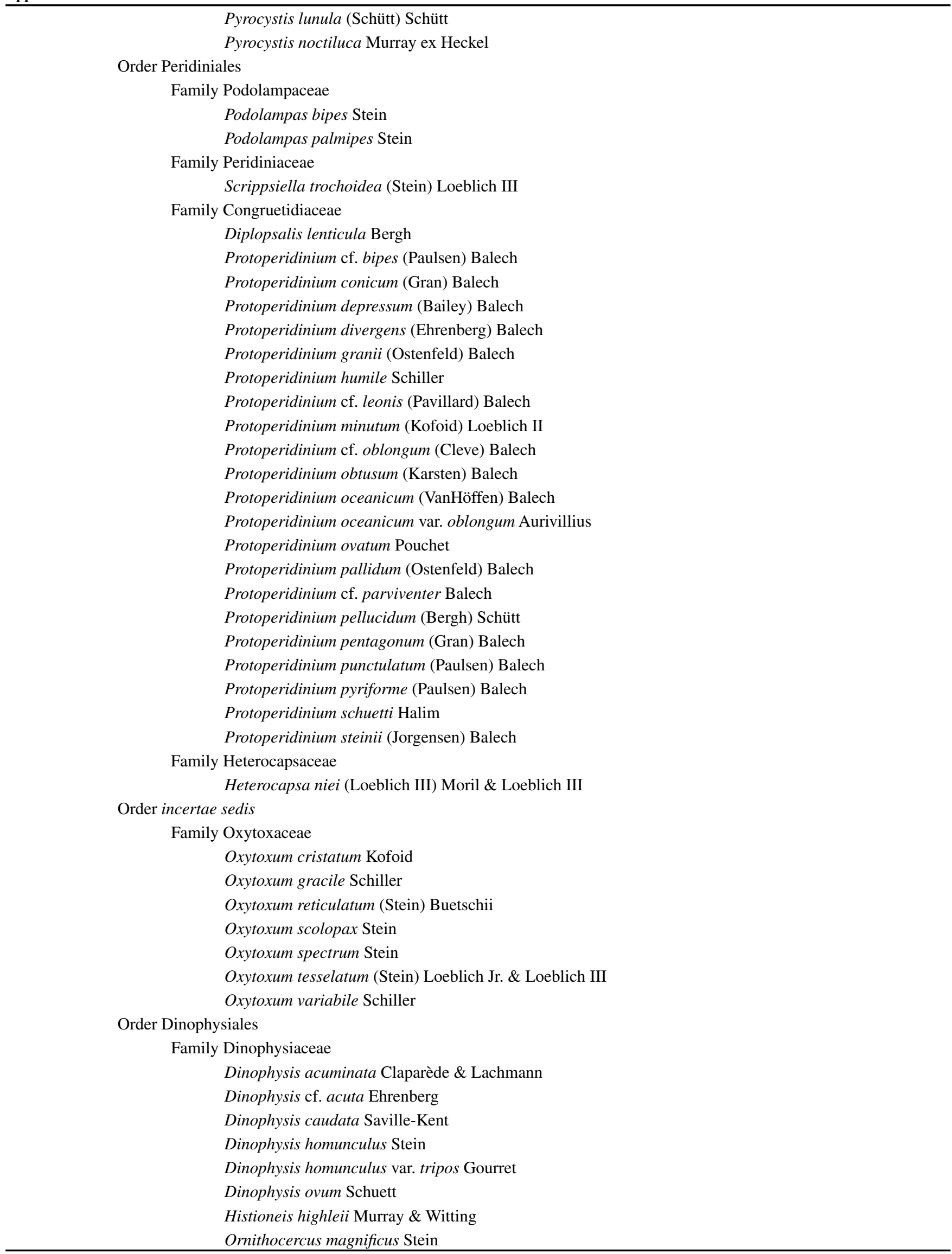




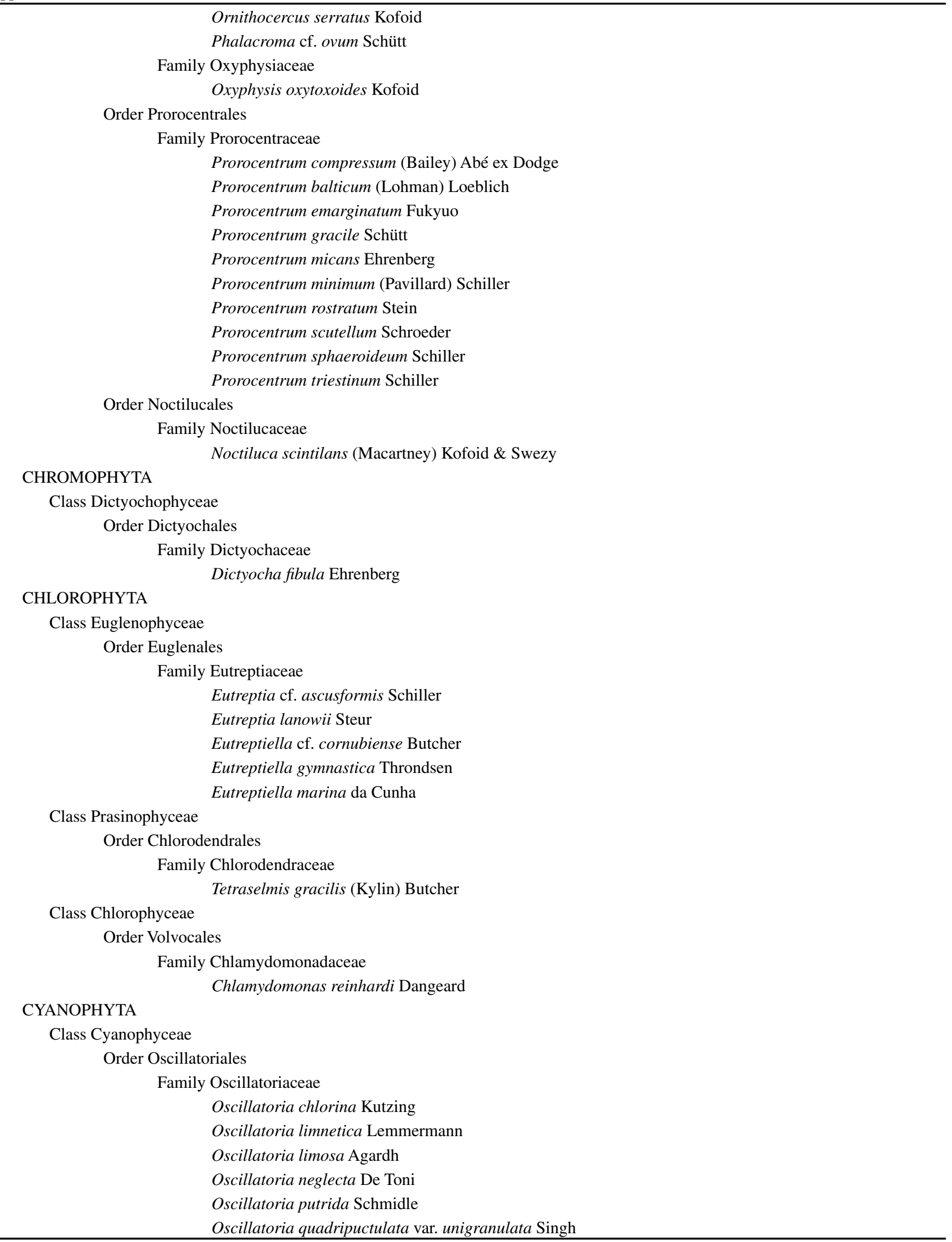


Appendix 2. Continued...

Family Phormidiaceae

Trichodesmium erythraeum Ehrenberg

Trichodesmium thiebautii Gomont

Order Nostocales

Family Nostocaceae

Richelia intracellularis Schmidt

\section{SARCOMASTIGOPHORA}

Class Zoomastigophorea

Order Ebriida

Family Ebriidade

Ebria tripartita (Schumann) Lemmermann

Family Ebriopsidae

Hermesinum adriaticum Zacharias 